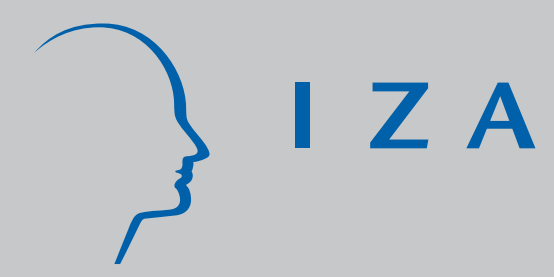

IZA DP No. 3027

Is Child Labor Harmful? The Impact of Working Earlier in Life on Adult Earnings

Patrick M. Emerson

André Portela Souza

September 2007 


\title{
Is Child Labor Harmful? The Impact of Working Earlier in Life on Adult Earnings
}

\author{
Patrick M. Emerson \\ Oregon State University \\ and IZA
}

\begin{abstract}
André Portela Souza
São Paulo School of Economics,

Fundação Getulio Vargas
\end{abstract}

\section{Discussion Paper No. 3027 \\ September 2007}

\author{
IZA \\ P.O. Box 7240 \\ 53072 Bonn \\ Germany \\ Phone: +49-228-3894-0 \\ Fax: +49-228-3894-180 \\ E-mail: iza@iza.org
}

\begin{abstract}
Any opinions expressed here are those of the author(s) and not those of the institute. Research disseminated by IZA may include views on policy, but the institute itself takes no institutional policy positions.
\end{abstract}

The Institute for the Study of Labor (IZA) in Bonn is a local and virtual international research center and a place of communication between science, politics and business. IZA is an independent nonprofit company supported by Deutsche Post World Net. The center is associated with the University of Bonn and offers a stimulating research environment through its research networks, research support, and visitors and doctoral programs. IZA engages in (i) original and internationally competitive research in all fields of labor economics, (ii) development of policy concepts, and (iii) dissemination of research results and concepts to the interested public.

IZA Discussion Papers often represent preliminary work and are circulated to encourage discussion. Citation of such a paper should account for its provisional character. A revised version may be available directly from the author. 


\section{ABSTRACT \\ Is Child Labor Harmful? The Impact of Working Earlier in Life on Adult Earnings}

This paper explores the question: is working as a child harmful to an individual in terms of adult outcomes in earnings? Though an extremely important question, little is known about the effect of child labor on adult outcomes. Estimations of an instrumental variables earnings model on data from Brazil show that child labor has a large negative impact on adult earnings for male children even when controlling for schooling and that the negative impact of starting to work as a child reverses at around ages 12-14.

JEL Classification: J31, O12, 054

Keywords: child labor, Brazil, adult outcomes

Corresponding author:

Patrick M. Emerson

Department of Economics

Oregon State University

Corvallis, Oregon 97331

USA

E-mail: patrick.emerson@oregonstate.edu

\footnotetext{
"For useful comments and advice, we thank Kaushik Basu, Christopher Dunn, Eric Edmonds, George Jakubson, Peter Orazem, Rodrigo Soares, and Ken Swinnerton. For excellent research assistance, we thank Carla Rossi. This paper has also benefited from seminar presentations at Cornell University, Ohio State University, Indiana University, Cal Poly - San Luis Obispo, Southern Illinois University, Getúlio Vargas Foundation, the 2007 World Bank/IZA Conference on Employment and Development, the 2007 American Economics Association Annual Conference, the 2006 Latin American Econometrics Society Meeting, the 2006 Brazilian Econometric Society Meetings, the 2005 Latin American and Caribbean Economics Association Conference, the 2004 Western Economic Association International Conference and the 2004 Northeast Universities Development Consortium Conference.
} 


\section{Is Child Labor Harmful? The Impact of Working Earlier in Life on Adult Earnings}

\section{Introduction}

Child labor is widespread in today’s world; the International Labour Organization estimates that 182 million of the world's children are child laborers, most living in developing countries. ${ }^{1}$ Recently, there has been a renewed interest in child labor issues, and this renewed interest has led to a series of studies that aim to understand the causes and consequences of child labor in order to guide appropriate policy responses (see Edmonds and Pavcnik (2005), Basu and Tzannatos (2003), and Basu (1999) for useful overviews and surveys of the theoretical and empirical literature). Among the policy options discussed are banning child labor and/or sanctioning countries that allow the practice. These types of policy responses have been widely debated among economists (see e.g., Emerson and Knabb, 2006, 2005, 2004; Horowitz and Wang, 2004; Basu, 2002; Dessy and Pallage, 2001; Baland and Robinson, 2000; Dessy, 2000; Basu and Van, 1998). Most of these studies emphasize the trade-off between child labor and human capital accumulation to justify policy interventions, arguing that there are large negative consequences from child labor. Child labor, however, is a broad term that encompasses a diversity of activities and working conditions, thus the belief that child labor is detrimental to human capital accumulation, may or may not be generally true, and, even if accurate, at what age does this adverse effect cease

\footnotetext{
${ }^{1}$ Child labor was also common in developed countries until fairly recently, see, e.g., Kruse and Mahony, 2000; Parsons and Goldin, 1989.
} 
to exist, and does the initial occupation matter, are open questions. ${ }^{2}$ Studying and providing robust estimates of the effects of starting to work as a child on adult earnings will allow future studies of child labor, and discussions of appropriate policy responses, to be informed by this research.

Though it is generally assumed to be detrimental, the potential effects of child labor on adult earnings are potentially twofold. On one hand, child labor can be detrimental through the hindering of the acquisition of formal education, both quantitatively and qualitatively, and causing irreparable damage to health, reputation or other things that effect adult human capital, which could lead to lower wages in the adult labor market. ${ }^{3}$ On the other hand, there may be positive pecuniary benefits to young labor: vocational training, learning by doing, general workplace experience as well as the potential for making contacts, learning job market strategies, etc. In other words, there are many reasons to expect that a young laborer can gain some human capital from their workplace experience (e.g., Horn, 1994). Furthermore, child labor could be a way to finance education that an individual would not otherwise have access to, which, in turn, could lead to better outcomes for older child or adolescent workers (see, e.g., Akabayashi and Psacharopoulos, 1999; Psacharopoulos, 1997). Thus the net effect of starting to work as a child is an empirical issue. Though virtually all studies of child labor assume it is harmful, there is as yet no reliable measure of the effects of working as a child on adult outcomes.

\footnotetext{
${ }^{2}$ It should be noted that there are some forms of child labor the are unequivocally bad: those that are detrimental to a child's health and well-being, those that involve indentured servitude or deny children their basic human rights, and those that involve psychological distress, to identify but a few. Some of these activities may not be detrimental to the adult earnings of the individual, but are indefensible nonetheless and we do not wish to suggest otherwise.

${ }^{3}$ Spindel (1985) argues that adolescent workers are more likely to end up in dead-end jobs that hamper their human capital development.
} 
The present study utilizes a very large household survey from Brazil that includes information on current working-age adults' attributes and incomes as well as retrospective information on the age at which they first started to work and the degree of school completion. Importantly, these data also include information on the educational attainment of the parents of many of the current working-age adults allowing controls for the family background of the subject individuals, something that is considered vital in the earnings regressions literature. To these data are added historical data that include population, number of schools by state and year, the number of teachers by state and year, and GDP data by state and year.

It is likely that individuals in this study have unobserved attributes (e.g. ability, ambition, etc.) that affect both their schooling and work choices and their adult earnings. Thus any attempt to estimate the effect of working early in life or attaining more schooling on adult earnings will be biased if this source of endogeneity is not properly addressed Estimates that do not attempt to address this issue are considered unreliable (Becker and Chiswick, 1966; Chiswick, 1974; Mincer, 1974). Much of the recent research into this relationship using US data has relied on the use of instrumental variables to overcome the confounding effects of these unobserved attributes (Cameron and Taber, 2004; Carneiro and Heckman, 2002; Card, 2001; Card, 1995a; Card, 1995b). The main drawback of this type of approach in this case is that it demands a robust set of instruments for the schooling and child labor choices of an individual. The historical data on the availability and quality of educational opportunities as well as proxies for local labor market conditions when an individual was a child allows such an approach to be followed. These institutional variables provide exogenous (to the individual household) variation in the cost and benefits of going to 
school and working and are therefore very likely to be correlated with the work and schooling decisions of children (regardless of who made these choices), yet uncorrelated with the unexplained variation in adult incomes (after controlling for adult labor market conditions, location, family background and other confounding effects). Statistical tests do not reject the validity of these instruments. ${ }^{4}$

A number of previous studies address the consequences of child labor - three of which deserve special mention. In Emerson and Souza (2003), we included an estimate of the impact of child labor on adult earnings in Brazil in a paper that was primarily concerned with the intergenerational transmission of child labor. In that paper we found results that are similar to the OLS results in the current study, but we were unable to control for potentially endogenous variables, however, and the results were, therefore, only suggestive. ${ }^{5}$ Illahi, Orazem and Sedlacek (2001) present results of a related exercise using similar data from Brazil but where a dichotomous child labor variable is utilized and the impact of having been a child laborer is measured on adult earnings and the incidence of poverty. They find a negative effect of child labor on adult wages, both through the loss of schooling and over and above the loss of schooling, and a higher probability of being impoverished if an individual was a child laborer. The use of the dichotomous variable prevents the study of the effects of starting to work at different ages, as is done in this paper. That study also suffers from the inability to properly control for potentially endogenous variables, however, and thus the results must be considered with a modicum of caution. Finally, Beegle, Dehejia and Gatti

\footnotetext{
${ }^{4}$ Duflo (2001, 2004), in a set of very interesting studies, exploits a rapid expansion of education supply in Indonesia and the varying treatment effects for individuals depending on the amount of exposure to the expansion the individual experienced. Brazil experienced no equivalent rapid expansion of education supply so we are unable to utilize similar methodology. However, Brazil's education expansion was not uniform and so the variability of education system expansion over time in different states means that different individuals were exposed to quite different education infrastructure, see the discussion of the instruments in section 3.
} 
(2004) examine the effect of child labor on the education and incomes of a small group of rural Vietnamese schoolchildren. They exploit a data set that observes a group of 8-13 year old children who are currently enrolled in school, some of whom work and some who don't, and examine the effect of having worked at the time of the first observation with their school attendance, school attainment, school progress and work and wage outcomes five years later. Most interestingly, perhaps, is the impact that child labor had on lowering school attendance and achievement. However, since they were still no more than 18 years old at the second observation, they were unable to look at adult outcomes. In addition, as the data were from a very small group of rural Vietnamese schoolchildren, it is difficult to extrapolate to a wider population. ${ }^{6}$

With the estimation strategy employed in this paper, it is possible to provide a very detailed description of the effects of child labor on adult incomes both including the effect of lost education and the effect over-and-above the effect on education. The main empirical finding of this study is that the effect of entering the labor market is negative for young children in this sample and that those negative effects turn positive between 12 and 14 years old. These results should be of vital interest to researchers of child labor in their quest to understand both the causes and consequences of child labor.

The rest of this paper is organized as follows. Section 2 discusses the empirical strategy employed to explore the central questions of the paper. Section 3 describes the data utilized in this study. Section 4 presents the results of the empirical estimations. Section 5 discusses the results and implications.

\footnotetext{
${ }^{5}$ Also related is an earlier version of the present study, which did not control for the effects of potentially endogenous variables: Emerson and Souza (2002).

${ }^{6}$ Other studies on outcomes include: Kassouf, et. al., (2001) which examines the impact of early labor market entry on adult health outcomes in Brazil but does not address the endogeneity issue; Manacorda (2006)
} 


\section{Empirical Strategy}

In order to fix ideas, consider the typical Mincerian framework of the effect of schooling on adult earnings in the high income country context. The discussion of the empirical issues usually begins with a presentation of a standard two equation system that describes schooling $\left(\mathrm{S}_{\mathrm{i}}\right)$ and $\log$ wages $\left(\ln \mathrm{Y}_{\mathrm{i}}\right)$, for an individual $\mathrm{i}$ :

(1) $S_{i}=X_{i} \delta+v_{i}$,

(2) $\quad \ln Y_{i}=X_{i} \gamma+S_{i} \beta+v_{i}$.

In this case $\mathrm{X}_{\mathrm{i}}$ is a vector of observed attributes of the individual and $v_{i}$ and $v_{i}$ are the random error terms that are assumed to be uncorrelated with $X_{\mathrm{i}}$. The coefficient $\beta$ is a measure of the 'returns to education,' or average returns to education if this varies across individuals if $v_{i}$ and $v_{i}$ are uncorrelated.

It is quite likely that schooling is correlated with the unobserved component of the log earnings equation, however, due to, for example ability bias or measurement error in schooling (see, e.g. Griliches, 1977). ${ }^{7}$ Ability bias arises when individuals of high ability both acquire higher levels of schooling (because the returns are higher and/or the costs are lower) and earn higher wages in the adult labor market. If this is true for our sample, an estimation of the $\beta$ coefficient will be biased upwards. Measurement error in schooling can also bias the results if it induces a negative correlation between the errors of the observed schooling and earnings, which would bias the estimate of $\beta$ downward.

examines the effects of child labor supply on household labor supply decisions; and Orazem and Lee (2007), which studies long-term health outcomes of individuals in Brazil based on when they began working.

${ }^{7}$ See Card (1999) for an excellent overview of the issues and evidence concerning estimating the causal effect of education on earnings. 
The context of a low income country in which child labor is widespread presents another confounding effect: child labor itself. The decision to work as a child is likely correlated with the schooling decision and is also likely correlated with adult earnings. Fortunately, one aspect of child labor is observed: the age at which individuals first started to work. Therefore, in the low income country context, where child labor is widespread the schooling and child labor decision are both likely to affect adult incomes and are likely correlated, a description of this process would involve a three equation system for and individual i:

(3) $S_{i}=X_{i} \delta+v_{i}$,

(4) $C L_{i}=X_{i} \alpha+\psi_{i}$,

(5) $\quad \ln Y_{i}=X_{i} \gamma+S_{i} \beta+C L_{i} \phi+v_{i}$.

Where $C L_{i}$ is the age at which the individual first started to work, and $\psi_{i}$ is the unobserved random error term. In order for $\phi$ to be a measure of the effect of starting to work at a certain age (or average if it varies across individuals), $\psi_{i}$ and $v_{i}$ must be uncorrelated.

These error terms are likely correlated because the same ability bias that causes high ability individuals to choose more schooling may also cause those individuals to choose to start to work at an older age (biasing the coefficient estimate upward) or they may choose to start working at a younger age because ability may pay off in the child labor market as well as the adult labor market (biasing the coefficient estimate downward). Measurement error is another source of potential bias for the age started to work coefficient.

In this case, consistent estimates for the return to education and the effect of starting to work as a child can be obtained if there is a set of regressors, $\mathrm{Z}_{\mathrm{i}}$, that can be added to the 
vector $\mathrm{X}_{\mathrm{i}}$ that affect schooling but do not affect the unexplained component of earnings, and that affect the age an individual starts to work but not the unexplained component of earnings. This set of regressors must be sufficiently correlated with both schooling and the age started to work (i.e. have enough separate correlation with both variables that is separate from the correlation among the two variables), and sufficiently uncorrelated with the unexplained variation in adult earnings that they can be legitimately excluded from the earnings equation.

In this study, as we have information on the age the individual first started to work, the years of schooling the individual has obtained and their current log earnings, we shall estimate the following system of equations using a GMM instrumental variables regression:

(6) $S_{i}=X_{i} \mid Z_{i} \delta+v_{i}$,

(7) $C L_{i}=X_{i} \mid Z_{i} \alpha+\psi_{i}$,

(8) $\quad \ln Y_{i}=X_{i} \gamma+S_{i} \beta+C L_{i} \phi+\mathrm{v}_{i}$ with the estimating assumption that $E\left(Z_{i} v_{i}\right)=0$. We shall estimate the model both with and without the years of schooling variable to evaluate the impact of early entry into the labor market both including the effect on schooling and then, when including the schooling variable, the effect of early entry over and above the impact on schooling.

To estimate the models presented above, we run both a series of OLS regressions (i.e. ignoring potential endogeneity concerns) and a series of GMM IV regressions in order to capture the effect of being a young laborer on adult earnings. These regressions will estimate the direct impact and indirect impact (i.e. controlling for schooling) of being a young laborer on adult earnings. 


\section{The Data}

\subsection{Primary Data}

The main sources of data utilized in this study are two rounds of the Pesquisa Nacional por Amostragem a Domicílio (PNAD), from Instituto Brasileiro de Geografia e Estatística (IBGE), the Brazilian census bureau: 1988 and 1996. The PNAD is a yearly and nationally representative household survey (excepting the rural Amazon region) similar to the Current Population Survey in the U.S. It covers close to one hundred thousand households and includes information on the demographic and labor market characteristics of the households. Additionally, and of particular utility for the present study, the 1988 and 1996 surveys obtain retrospective information from the household head and the spouse (that are in the labor market) about the age they entered the labor market, their first occupation, the educational attainment of their parents as well as the occupation of their fathers when they (head and spouse) first entered the labor market, the state in which they were born and the state in which they currently reside. , $^{8}$

The parental education variables are crucial to our analysis. These provide important controls for the family background of the individual. As parental income is highly related to education, especially in Brazil, these variables, when included as explanatory variables, control for things like wealth, nutrition, overall education level in the household in which the

\footnotetext{
${ }^{8}$ If the two states were different, a follow-up question was asked about the number of years the individual had lived in the current state. This information was coded 1 through 10+ years. Because of the truncated and incomplete data, we are not able to construct a complete picture of migration, but we are able to utilize the information on those that are currently residing in a state that is not their birth state as a control for migration. A detailed discussion appears in section 4.3.

${ }^{9}$ The 1982 PNAD collects identical retrospective information of the heads and spouses as well. However, it does not contain information about their immigration status which is crucial to assign the corresponding instrument to the individual.
} 
individual grew up and parental decisions about where to live, what schools to send the children to and their own educational inputs for the children. ${ }^{10}$

Our sample consists of all males who were identified as household heads or the spouse of the household head between 25 and 55 years of age at each survey year. We exclude younger and older men in an attempt to avoid potential selectivity bias of labor market participation decisions. We also exclude females for three reasons: first, there is a large selection issue relating to the women who choose to work (less than 50 percent of women in the 1988 and 1996 PNADs were listed as currently employed); second, many girls work in the household rather than in the labor market leading to under-measurement of female child labor; and third, fertility issues complicate the school and work decisions of females.

Table A.1 of Appendix A presents the number of observations kept in our sample due to each criteria of the selection process. The 1988 and 1996 pooled sample of 25-to-55-yearold males encompasses 108,229 observations. Of these 101,901, or 94.15 percent, participate in the labor market, and 95,337, or 88.09 percent, work with strictly positive earnings in the labor market. ${ }^{11}$ Of all prime age male workers with strictly positive earnings, 80,587 , or 84.53 percent, are listed as the head of the household or the spouse of the head. We restrict the sample to heads and spouses since we have information about age started to work and family background only for these individuals. ${ }^{12}$ Among all prime age head and spouse males

\footnotetext{
${ }^{10}$ See Lam and Schoeni (1993) for an excellent study of family background effects in Brazil. There is also a large and growing literature on the intergenerational transmission of human capital (see, e.g., Black, et. al., 2005; Maurin, 2002; Keane and Wolpin, 2001; Neri, et. al., 2000; Shea, 2000; Blau, 1999; Lam and Duryea, 1999) that suggests that it is vitally important to control for family background. Family income is also important in Brazil specifically, see Duryea (1998).

${ }^{11}$ All earnings are in 1996 Reais. To convert the 1988 earnings, we used the Brazilian national CPI (specifically the INPC from IBGE).

${ }^{12}$ The 1996 PNAD contains the age start to work information for all workers. However, the family background information and first job occupation are asked of the heads and spouses only. Since we will make use of the
} 
working in the labor market with strictly positive earnings, we restrict the sample to those who declared their age started to work to be between 7 and 25 years old. 97.54 percent started to work in this age range. Finally, we further restrict the sample to those with valid information on their parent's schooling and birth state information. Doing so, we end up with a sample of 62,745 observations. The drop in the number of observations is mostly due to the lacuna of parental education information. Some respondents declared that they do not know their father's and/or their mother's educational attainment. Since we want to control for family background, we exclude these individuals from our final sample as well. ${ }^{13}$

We perform all of our subsequent analyses on the pooled sample of the 1988 and 1996 PNADs. In our regression analysis, we control for both from which sample the information was obtained and the cohort of the individual. ${ }^{14}$ The basic statistics of the sample are presented in Table A.2 of Appendix A.

It is informative to examine the distribution of the age the individuals in our sample first started to work, their schooling distribution, and their schooling attainment and logearnings by the age they first started to work. Figure 1 shows the distribution of age started to work for all individuals in our sample. Note that there are spikes at 10 years old, the age at the end of the lower primary school, 12 years old, the legal minimum working age until 1988, 14 years old, the end of upper primary school, and 18 years old, then end of secondary

\footnotetext{
father's occupation and first job occupation information, and want to be consistent with the 1988 PNAD, we keep in our sample only the heads and spouses for the 1996 PNAD.

${ }^{13}$ Individuals that have missing parental education information have disproportionately lower education, slightly lower earnings and started to work slightly earlier than those that do have information on their parents' education. Because this sample selection may bias the results, we estimated the same regression models including those that do not have parental education and assigning them the sample average parental education and included an indicator variable for them. The results were qualitatively identical and quantitatively very similar. Results are available upon request.

${ }^{14}$ The cohorts are split by those that were born before 1959 and those that were born after 1958. The reason for this particular division was that those in the younger cohort are the ones that would have been affected by the education reform enacted in 1972 that increased the mandatory schooling age from 10 to 14 .
} 
school. Figure 2 shows the years of schooling distribution. The distribution presents four major spikes corresponding to the Brazilian education system. Around 15 percent are illiterate (0 years of schooling), 18 percent have 4 years of schooling (lower primary completion), 9 percent have 8 years of schooling (upper primary completion), and 13 percent have 11 years of schooling (high school completion). Note that less then 10 percent have completed a college degree (corresponding to 15 years of schooling or more).

The Figures 1 and 2 collapse all individuals that come from different cohorts, and it is likely that the educational attainment and entry age in the labor market have evolved during the interval in question. Figure 3 presents the average years of schooling and the average age started to work by the year of birth of the individuals in the sample. The oldest individuals in our sample were born in 1933 and the youngest individuals in 1971. Although the average schooling and average age started to work increased along the years, as one would expect, it is perhaps remarkable for how slowly these have increased. Indeed, the average years of schooling among our sample individuals is around 3.5 years of schooling for individuals born in 1933, and 7 years of schooling for those born in 1971. Not only is the schooling level low compared to other developing economies, it has also progressed at a slower rate - it took almost 40 years to double this number. ${ }^{15}$ Similarly, the average age started to work increased very little. Among those born in 1933, this average was around 12 years old. For those born in 1971, it was 13.5 years old. That is, during the intervening 38 years it increased by only 1.5 years. Thus, for the generations in our sample, by the beginning of their adolescence the majority of the Brazilian male individuals were engaged in labor market activities.

Figures 1 to 3 tell us three things: (i) the average Brazilian male worker has low educational attainment and starts to work at a relatively young age; (ii) the average years of 
schooling and average age started to work have increased during the sample window, but not by very much; and (iii) there is a sizable dispersion of the years of schooling and of the age started to work distributions. It is useful to explore how they are related to each other, and how both are related to the earnings of the individual when they are adults. Figure 4 allows us to begin to do so. It shows the schooling attainment and log-earnings by age started to work. Note that both the schooling by age started to work and the log-earnings by age started to work are increasing in general and appear to be moving together. This begs the question, is there a causal relation between age started to work and adult earnings, and if so is the impact of starting to work at a younger age on log-earnings only a schooling effect? In other words, the effect of starting to work at a younger age could be indirect (through education), direct (over and above the effect on educational attainment), or both.

\subsection{Age Started to Work}

In order to investigate the transition to work of individuals in Brazil, we utilize the response to the question posed in both rounds of the PNAD which we employ, "at what age did you start to work?” This question is asked for those heads and spouses active in the labor market in the 1988 PNAD, and for all occupied individuals in the 1996 PNAD.

Though it is impossible to say precisely how respondents understood this question, there is a fair amount of evidence to believe that they understood it to mean regular work. First, this question is only asked for those currently engaged in labor market activities. Second, the age started work question belongs to the part of the questionnaire devoted to the mobility characteristics in 1988 and to the labor market characteristics in 1996. In both cases it is preceded by a series of questions asking the respondents about their current work, earnings, hours, occupation, sector, their previous work and occupations, and then was

\footnotetext{
${ }^{15}$ See, for example, Birdsall and Sabot's (1996) discussion on educational outcomes in Brazil.
} 
followed by questions asking about their occupation in the job in which they indicated they first started to work in, and their father’s occupation at that time. For this reason it seems very likely that the respondents understood that the interviewer was interested in regular work. Third, we can construct incidence rates from our retrospective data on age started to work and compare it with other estimates of historical child labor incidence in Brazil.

We construct the level of child labor incidence in our data in the following way, for both surveys we determined which 25-to-55-year old male individuals were 10 to 14,15 to 19 and 20 to 24 in the years 1950, 1960, 1970, 1980 and 1990. We then determined if they had reported that they had already begun to work. ${ }^{16}$ We then found the ratio of male workers to all male individuals in each age category for each year. We compare these with the estimates of child labor incidence among Brazilian males for the same age categories and for the same years from the International Labour Organization (ILO). The ILO figures refer to individuals currently active in the labor market at that time. These comparisons are presented in Table 3. A couple of patterns are worth noting. First, for the 10 to 14 age range, the contemporaneous incidence of child labor (ILO data) is smaller than the retrospective information for all years (PNAD data). Second, for the 15 to 19 and 20 to 24 age ranges, the ILO and PNAD figures are similar and in most cases the PNAD figures are somewhat smaller than the ILO ones. If the individuals had interpreted the age started to work question as it referred to sporadic or irregular work, we would observe higher incidence for the retrospective information for all age ranges.

\footnotetext{
${ }^{16}$ For those that were working at the time of the survey. For the others we assumed that they were not working. For instance, a 46-year-old individual in 1996 was born in the year 1950. If he had declared that started to work at age 10 or below we assigned him as a child laborer in the 10 to 14 age range in the year 1960 and in the 20 to 24 age range in 1970. We would consider him a non-child laborer in this age range otherwise.
} 
The significant differences seem to concentrate in the 10 to 14 age range only. These discrepancies may be due to the fact that the work of those that responded to have started to work younger in life are more likely to be part-time work, home farming, or home production that the ILO figures may not capture.

\subsection{School and Work}

To further understand how Brazilian children used their time during the period of study, we examine the joint nature of the work and school decisions. The formal primary and secondary school hours in Brazil are only 4 a day: either the entire morning or the entire afternoon. It is, therefore, quite possible for a child or adolescent to attend school in one period and work in the other. In fact, in our sample the majority of those that worked as a child also attended school. It is precisely because of the simultaneity of work and school activities that we are able to empirically identify the trade-off between work and school. To support this point, we present two complementary pieces of information that provide further insight into the time allocation decisions of Brazilian boys in Appendix B.

\subsection{The Instruments}

As mentioned in the empirical strategy section, in order to properly control for the potential endogeneity of the age started to work and schooling variables in the earnings regressions, the instruments must be both relevant and valid: well-correlated with the potentially endogenous variables and uncorrelated with the unexplained variation in earnings. One set of variables that are likely to fulfill this requirement are the number of schools per children in the individual's state in the year that they are 7 years old, 11 years old and 15 years old, the number of teachers per school in the individual's state in the year that they are 7 years old, 11 years old and 15 years old, and the individual's state's GDP per capita when 
the individual was 12 years old. The presence of more schools in the same state of the individual lowers the cost of attending school as travel costs are reduced and students are more likely to be able to live at home and attend school. Age 7 is the age when an individual first enters school, 11 is the start of the upper primary levels of school and 15 is the beginning of secondary school for a normally progressing child (i.e. no delays). Lower cost of education should increase investments in education, and cause delay in starting to work. This variation in the supply of schooling is also exogenous to the individual decision maker and should be uncorrelated with adult incomes once the family background and adult economic conditions in their location are controlled for. Similarly the number of teachers per school is a source of exogenous (to the household) variation in both the benefit and cost of attending school. The GDP per capita is a measure of local economic conditions, and the age of 12 is critical decision year as 12 was (until 1988) the minimum legal working age in Brazil. This variation in local labor market conditions is exogenous to the individual decision maker and is likely correlated with the decisions to enter the labor market and to finish schooling. These data are the set of instruments employed in all instrumental variable regressions. A similar identification strategy was employed by Card (1995) and Cameron and Taber (2004).

The data on the number of primary and secondary schools by state and year, the number of teachers per state per year, and the population by state and year come from the IBGE Historical Series, 2003. Data on the GDP per state per year were obtained from the Instituto de Pesquisa Econômica Aplicada (IPEA) historical series. ${ }^{17}$ In order to match each individual with the number of schools, teachers and the GDP in their state for each year that

\footnotetext{
${ }^{17}$ IPEA is the research institute of the Ministery of Planning of the Brazilian Federal Government. These series can be obtained on line in http://www.ipeadata.gov.br/ipeaweb.dll/ipeadata?1026025750.
} 
they were school aged, we give the individual the schools, teachers and GDP of their birth state. $^{18}$

Thus, the instruments we use for the results presented below are the birth state number of primary and secondary schools per thousand children aged 5 to 19 when the individual was 7, 11 and 15 years old, and the birth state number of teachers per primary and secondary school when the individual was 7, 11, and 15 years old and the birth state GDP per capita at age 12. The GDP is given in thousands of Reais (Brazilian currency) for year 2000. Their basic statistics are shown in Table A.2 of Appendix A. The details of how these series were constructed are given in Appendix C.

There are 25 states and 39 birth years from 1933 to $1971 .^{19}$ Thus each instrument has 975 different values and these are the source of the variation that we exploit to identify the model. The figures for Brazil and some selected states from different regions are presented in Figures 5.a to 5.c. São Paulo and Piauí are the richest and poorest states in Brazil, respectively. Minas Gerais and Rio Grande do Sul are states with GDP per Capita similar to the country's GDP per Capita. The number of schools per thousand children aged 5 to 19 years old for the country ranged from between 2 and 3 in the early 1940s to 4 to 5 in the early 1980s. The number of teachers per school ranged from 2 in the beginning of the 1940s to 6 in 1985. The GDP per Capita remained relatively stable from the 1940s to the late 1960s.

\footnotetext{
${ }^{18} 38 \%$ of our sample are formed by individuals that the current state of residence is not the state of birth. Our procedure assumes that these individuals were likely to attend schools in their birth state. However, we do not know when they left their birth state. In order to check the robustness of our results, we also followed two procedures. First, we replicate the exercise adding a migrant indicator variable as control. This procedure is presented in the results. Second, if the individual was a current resident of the same state in which they were born, we assume that they have not migrated and give them the number of schools associated with that state. If they list a birth state different from the state in which they were current residents of and the migration information does not allow us to determine exactly when they moved, we give them the national average number of schools for each year they were of school age. The results are qualitatively the same.

${ }^{19}$ Brazil has 27 states currently. We collapsed the states of Goias and Tocantins, and the states of Mato Grosso and Mato Grosso do Sul. Tocantins and Mato Grosso do Sul were created recently from a division of the old
} 
The 1970s experienced a rapid economic growth where the GDP per Capita doubled in ten years, the so-called 'Brazilian economic miracle' years. After the economic crisis in the early 1980s, the GDP per capita leveled off and growth has been relatively slow. More importantly for our analysis, there are sizable variations across states. Interestingly, some states like Sao Paulo have below average schools per children but above average teachers per school. Thus there appears to be two ways to expand schools in states, build more schools, or expand current ones with more teachers.

\section{Estimation and Results}

\subsection{The Effect of Starting to Work Earlier in Life}

In order to estimate the effect of having been a child worker on current adult earnings, we start by estimating two separate earnings equations that include the age the individual first started to work variable and its square, the age of the individual and its square, indicator variables that equal one if the individual is classified as black and another if the individual is classified as 'pardo,' or mixed race. Included in all estimations are measures of the fathers and mothers education levels to control for family background. For fathers and mothers we include indicators for each level of education completed: some to completed lower primary, beyond lower primary to completed upper primary, beyond upper primary to completed secondary and beyond secondary to completed college. The reference category is if the parents have not attended any school. Not properly controlling for family background can bias our results: richer children are more likely stay in school and enter the labor market later and poorer children more likely to abandon school and start to work early. In addition,

Goias and old Mato Grosso, respectively. Some territories were transformed into states and some states were merged along the $20^{\text {th }}$ century. For details of how the sates were aggregated see Appendix E. 
wealthy and more educated households may choose to locate near good schools, in good neighborhoods, etc. If we are not properly controlling for family background we may be underestimating the turning point of the age started to work. Also included is an indicator variable that equals one if the individual resides in a rural area, as well as the year of the survey and the cohort control. We include birth region indicator variables in an attempt to control for regional specificities (e.g., educational policies or labor market institutions) associated with schooling, age started to work and earnings. The birth regions are North, Northeast, East, South and Center-West and follow the official administrative group of states as of the late $1960 \mathrm{~s}^{20}$ The difference in the two separate earnings equations is that in the first estimations the years of schooling of the individual are not included and in the second set, the years of schooling are included.

We begin by estimating the earnings model first by OLS and then using the set of instruments described above in a GMM IV framework. The first set of regressions does not control for the individual's educational attainment. The fact that an individual worked during childhood or adolescence will likely mean that individual will have attained less education than a similar individual that did not work. So, as a first step, the coefficients of the age started work variables when not controlling for education capture the expected forgone adult earnings of a young worker. Then, when controlling for schooling, the coefficients on the age started to work variables capture the effect on adult earnings holding education constant.

Table 2 presents the OLS coefficient estimates where years of schooling is first excluded and then included. The first column estimates indicate that there is a benefit to delaying entry into the work force and that its effect is slightly convex. The second column results indicate that there is about an eleven percent per year increase in adult earnings for

\footnotetext{
${ }^{20}$ The regional division is presented in Appendix E.
} 
each additional year of schooling. Additionally, as we are interested in the young laborer status of the individual and its impact on his adult earnings, the coefficient estimates show that the older the individual enters the labor market, the higher are his earnings (even after we control for the effect of the loss of education). If we take these results at their face value, we would be inclined to conclude that starting to work at a younger age is highly costly in terms of adult earnings. There is a negative impact of child labor through foregone earnings (due to foregone schooling), and there is also a negative impact over and above schooling well into adulthood. However, as argued at length above, both years of schooling and age started to work and its square are likely endogenous in the OLS regressions. Therefore we turn to the GMM IV regressions. We first estimate the GMM IV models without controlling for years of schooling and we then include schooling controls. ${ }^{21}$

Table A.3 of Appendix A presents the first-stage regression results for this specification (model 3.a). For both the age started to work and its square, the F test of the included instruments are all above 12 , indicating that they are jointly strongly correlated with the endogenous variables. The number of schools per children and the number of teachers per school are positively associated with age started to work and its square and GDP per capita is negatively associated with age started to work and its square. ${ }^{22}$ As expected, lower cost of schooling and lower opportunity cost of schooling is likely to delay the child's entry in the labor market. Table A.3 also presents the first stage regressions for the model that controls for schooling (3.b). The instruments are jointly strongly correlated with the variable years of schooling as shown by the F test of 25 .

\footnotetext{
${ }^{21}$ All GMM IV regressions allow for clusters by birth state and year.

22 There are some negative individual coefficient estimates, but as educational expansion in Brazil was likely driven to some extent by poverty considerations this is not too suprising.
} 
Table 3 presents the results of the second stage IV estimation of the models. The IV estimates of age started to work are significantly higher than the OLS, but the squared term is now negative and significant, so the overall effect depends on the age of analysis. These IV results suggest that the overall negative effect of starting to work at a younger age end at age 14 as presented in the last line of Table 3. Thus, for the model that does not control for schooling (models 3.a) there is a negative and significant impact on adult earnings if a male individual started to work as a child at or below the age of 14, but that effect becomes positive for individuals who started to work after age 14. The Hansen's J-Statistic test of over-identifying restrictions confirms that the null hypothesis (of instrument orthogonality to the error terms) is not rejected. ${ }^{23}$

The next estimation was performed on the model where the variable 'years of schooling' is included as a control variable in the second stage. The second stage regression results are presented in model 3.b of Table 3. Here, the coefficient estimates of the age started to work variable reflect the effect on adult earnings of having been a young laborer over-and-above the loss of education. Note that in the IV estimation, the coefficient on the years of schooling variable is a $13.4 \%$ increase in adult earnings per additional year of schooling. The age started to work coefficient estimate is again positive but its square is negative. This is consistent with the results of the estimation of the model that excluded years of schooling in that the age at which the negative effect ceases is at age 13.2. Interestingly, there is no significant difference of the age started to work that maximizes adult earnings when education is controlled for. Thus, starting to work below 13 - 14 years old harms the expected adult earnings even if the individual attends school regularly.

\footnotetext{
${ }^{23}$ Qualitatively similar results for this and all subsequent regressions were obtained when we controlled for the father's occupation when the individual first started to work as an additional family background control.
} 
For both estimations, the other coefficient estimates have the expected signs. Older individuals have higher earnings but this increases at a decreasing rate, black and pardo individuals have systematically lower earnings than white individuals, individuals in rural areas have lower earnings, and, the more educated the parents, the greater are the earnings of the individuals. The '33-'58 cohort indicator variable estimate is positive and significant in both cases and, interestingly, individuals from the earlier sample, 1988, have systematically lower earnings, perhaps reflecting the growth of the Brazilian economy over the intervening years. ${ }^{24}$ Individuals born in the North and the Northeast regions, historically the two poorest regions of the country, have lower earnings. ${ }^{25}$

The estimates of the log earnings equations may still be biased if: one, there is persistence in differential state labor market conditions; two, certain types of individuals might have migrated to look for better schools and/or better wages and thus this opportunistic migration is driving the result; and three, that school quality may not be properly controlled for and is therefore contaminating the result. The next three sections address each of these concerns.

\subsection{Potential Bias from Persistence of Labor Market Conditions}

The results of Table 3 suggest that there is indeed a negative impact of being a child laborer both including the effect on educational attainment and over and above the impact on education. However, this effect seems to subside and turn positive at around age 13-14. Of course, these results are valid under our assumption of the exclusion restrictions. Cameron and Taber (2004), among others, argue that earlier labor market conditions are possibly correlated with later labor market conditions. If this is the case, the use of previous labor

\footnotetext{
${ }^{24}$ The 1998 indicator variable could also capture some systematic differences in the surveys themselves.
} 
market condition proxies as instruments is only valid if we control for later labor market conditions as well. For instance, better labor market conditions when the individual is 12 years old may be associated with dropping out of school and starting to work earlier in life. It may also be associated with better labor market conditions when the individual is adult. If we do not control for adult labor market conditions, we may be attributing earlier labor market experience to higher adult earnings when in fact it is due to the overall labor market conditions. In other words, our 'ideal' labor market entry age is biased downward. It may also be the case that good labor market conditions as a child may delay entry in the labor market as adult incomes in the household may be sufficient to provide adequate nutrition and thus freeing children to attend more school - potentially biasing the 'ideal’ entry age upward.

In order to control for this potential bias problem, we estimate an alternative specification that includes the birth state GDP per capita when the individual was 25 years

old as an exogenous variable. The second stage regression results are presented in Table $4 .^{26}$ From these results we can see that there remains a negative impact of being a child labor both including the effect on schooling and over and above the impact on schooling. This effect seems to subside and turn positive at around age 12. Thus, the results of Table 3 remain qualitatively the same when we control with a proxy for adult labor market conditions though we see the turning point in the age started to work move a bit younger suggesting perhaps some bias arising from the failure to control for the adult local economic conditions.

\subsection{Potential Bias from Opportunistic Migration}

Another source of potential bias in the estimations above is the lack of a control for migration. 38 percent of the observations in our sample consist of individuals living in a

\footnotetext{
${ }^{25}$ We also estimated the regressions with years of schooling and its square. The coefficients of the squared term were not statistically different from zero.
} 
state different from their birth state. The potential for bias arises if there is some underlying selection process where the migration decision depends on some unobservable individual characteristics correlated with schooling or child labor and associated with adult earnings. For example, ability and motivation could be positively correlated to schooling, earnings, and willingness to migrate. A higher ability or more motivated individual may be more likely to migrate to a place where one can get a better education and a better job as an adult. In this case the migrant is potentially more likely to postpone the entry in the labor market. Without controlling for migration our estimations may be biased upward. On the other hand, there may be a selection process that biases the estimations downward. For instance, a higher ability or more motivated individual may be more likely to migrate to a place where one can get a better job as a child and where it is possible to move up the income distribution faster through occupational choices.

Table 5 presents the results for both models where we keep the birth state GDP per capita and add the migrant indicator variable as a control. ${ }^{27}$ Since migration is a choice variable it is very likely to be endogenous and we treat it as such. All the results are qualitatively similar to the ones of Tables 3 and 4 with the caveat that the returns to schooling become somewhat greater now. More importantly for our purpose here, however, the turning point of age to start to work is 11.5 and 13 years old for the model without and with schooling, respectively, consistent with earlier results. Again, the negative impact of being a child labor persists with and without including the years of schooling.

\footnotetext{
${ }^{26}$ The first stage regressions are presented in Appendix A, Table A.4.

27 The first stage regressions are presented in Appendix A, Table A.5.
} 


\subsection{Potential Bias from Differential School Quality}

In our previous specifications we used the number of schools per population of children in the state as an instrument for the schooling and work decisions. Our use of number of teachers may be proxying for school quality, however, and school quality may matter in terms of human capital accumulation and adult productivity. If this is true than the number of teachers would potentially be correlated with unexplained adult earnings and would not be valid instruments. This is, however, unlikely in our view as the family background controls in the second stage are likely to capture school quality that is correlated with the wealth of the family, attitudes towards education and other factors that may drive the households location choice and thus the quality of school the child would have experienced. ${ }^{28}$ However, as a further robustness check we estimated models where the average number of teachers per school from when the individual was 7 to 14 years old was included in the second stage regressions to control for school quality (the number of teachers per school were thus not used as instruments). We keep the migrant indicator variable as an endogenous variable and birth sate GDP per capita at age 25 as a control. Note that in the cases in which schooling is controlled for, there are four instruments and four endogenous variables and so the model is just identified.

Table 6 presents the second stage results for both models. ${ }^{29}$ The results are qualitatively the same and the average number of teachers per school variable is not significant. Thus the education of the mother and father that are included as controls in the earnings equations are probably sufficient controls for school quality. Once more, for both models, there is a negative impact of being a child labor both including the effect on

\footnotetext{
${ }^{28}$ Parental education and family income and wealth are highly correlated in Brazil. See, e.g., Emerson and Souza (2003).
} 
schooling and over and above the impact on schooling. This effect seems to subside and turn positive at around age 14.

\subsection{Discussion}

Our results suggest that there is a negative impact of being a child laborer on the individuals’ adult earnings. This negative effect ceases around ages 12-14 and there appears to be positive impacts on adult earnings from adolescent labor. The negative effects before 12-14 and positive effects after 12-14 operate both through the effect on schooling as well as over and above the effect on schooling.

In order to illustrate the magnitudes of the impacts of early entry in the labor market, Figures 6 depicts the marginal impacts (in log points) of the age started to work on adult logearnings when we control for schooling (for models 3.a, 4.a, 5.a and 6.a.). The marginal impacts are evaluated at each age started to work from age 9 to 18 . Though not shown, the estimated marginal impacts without schooling and with the schooling control are not statistically different to each other for all evaluated ages from 7 to 25 (at the 5 percent level). This suggests that most of the negative effect of child labor works over and above the effect on schooling. Although the point estimates vary across models, the trend is always the same: there is a downward trend where the marginal impact reverses its sign around $12-14$ years of age. Table 7 shows the point estimate of the age started to work that maximizes adult earnings for all models. It also includes the standard deviations and the 95\% confidence interval. The estimates vary a little across models but the qualitative result is the same: there is a negative impact on adult earnings if an individual starts to work early in life. This negative effect seems to subside and becomes positive around ages 12-14.

\footnotetext{
${ }^{29}$ The first stage regressions are presented in Appendix A, Table A.6.
} 
Our estimation also allows us to estimate the adult earning trade-off between work and school. Figure 7 presents an 'iso-earnings' curve that represents the trade-off between education and child labor based on the estimated coefficients from model 3.b. The slope of this curve illustrates how much extra schooling is needed if the individual enters the labor market one year earlier in order to keep the same earnings level as an adult. For younger individuals this slope can be greater than one in absolute value. It means that if a child starts to work one year earlier and does not go to school, the loss in his adult earnings is equivalent to having lost more than one extra year of schooling. Conversely, if older children postpone their entry in the labor market by one year, the loss in his adult earnings is potentially equivalent to having lost more than one extra year of schooling.

Even though we are interested in years of schooling primarily as a control, our results are related to the returns to education literature in the U.S. Like similar studies of the education - earnings relationship in the United States and elsewhere, our IV regression coefficient estimates on the schooling variable are consistently above the OLS coefficient estimates. This may seem counter-intuitive if one believes that ability bias biases the OLS schooling coefficient estimates upward. However, as ability may also increase the opportunity cost of schooling (because high ability children may earn more in the child labor market), this could lead to a downward bias in the OLS estimates. In addition, as Griliches (1977) and others have pointed out, measurement error in the schooling variable can lead to a downward attenuation bias in the OLS schooling coefficient estimate, something that IV, as long as the instruments are not correlated with the measurement error, corrects for. As we are using retrospective information on schooling, there may be a large degree of mismeasurement. Finally, as Card (1999) points out, if the individuals for whom school location 
is most important in determining their education (perhaps due to credit constraints) are also the ones who have the highest marginal impact from schooling, then school location as an instrument will emphasize their contribution to the overall effect.

As our primary research question is based on the estimate of the age started to work coefficient, similar questions can be raised about the difference in the OLS and IV estimates. The point estimates for the age started to work coefficient rise considerably and the coefficient on the age started to work squared term are also large and significant in contrast to the OLS estimates. This may be due to similar issues with attenuation bias as retrospective information on individuals first work experience is likely to suffer from mismeasurement. Ability bias could also be important for age started to work as well. In addition if there are heterogeneous returns to working early that are correlated with the proximity to schools, the coefficients could be capturing this as well. If the instruments are valid than these biases would disappear in the IV estimates and could account for the difference between them and the OLS estimates.

\section{Conclusion}

This paper investigated the effect of starting to work as a child laborer on an individual's adult earnings in order to fill a substantial gap in our understanding of the consequences of child labor. We find that child labor is associated with lower adult earnings, partly due to the trade-off associated with educational attainment and mostly partly due to the effect over and above the impact on educational attainment, but that this negative net effect appears to reverse around ages 12-14. 
It should be noted that it would be wrong to conclude from these findings that, for contemporary male children in Brazil, the ideal age to start to work is in adolescence (age 13 or so) if the aim is to maximize adult earnings. However, when considering the environment that the individuals in this study grew up in, their decisions to start working could have been rational. Since the individuals in our sample are males born between 1933 and 1971 (for the older cohort especially) most of the individuals were living in poor families in rural areas. By today's standards those individuals, on average, faced a narrow supply of schools and teachers and had low life expectancy. Capital markets were not very well developed at this time in Brazil as well, and it is quite likely that poor Brazilians faced credit constraints. With relatively high interest rates and relatively low life expectancy it may have been quite rational to discount the future very highly and decide to start to work younger in life to earn income immediately rather than delay in order to capture potentially higher income in the future. For contemporary children, the environment has changed quite dramatically and therefore, it may well be better to delay the work commencement age well into adolescence. Contemporary Brazil is, however, quite farther advanced, in terms of GDP per capita, than many other low-income countries. For contemporary economies that are similar to the Brazil of this era, the results presented in this paper are potentially quite relevant.

What is perhaps the most striking element of the results presented here is the fact that, even in a very low-income environment where opportunities are scarce, there are negative consequences of entering the labor market at a young age. This presents, then, a challenge to policy makers who are attempting to reduce the incidence of young work: even if economic conditions are very poor, children who work ay very young ages appear to suffer significant negative consequences as adults. It is also striking that the negative effects of starting to 
work at a very young age exist even when controlling for the years of schooling. This suggests that perhaps it is not enough just to get children into school, it may also be equally or more important to curtail their work activities. Understanding the processes that drive these results is, therefore, an important area of future research in order to better inform policy makers. Overall, however, given the improvement in the situation of Brazilian children through time, it may be that the most effective policy interventions to combat child labor are those that improve life expectancy, school availability and quality, and those that ease credit constraints. 


\section{REFERENCES}

Akabayashi, Hideo and George Psacharopolous. (1999) "The Trade-off Between Child Labor and Human Capital Formation: A Tanzanian Case Study,” Journal of Development Studies, v. 35, June.

Baland, Jean-Marie, and James A. Robinson. (2000) “Is Child Labor Inefficient?,” Journal of Political Economy, Vol. 108, n. 4, pp. 663-679.

Basu, Kaushik. (2002) “A Note on Multiple General Equilibria with Child Labor,” Economics Letters, Vol. 74, n. 3, pp. 301-308.

Basu, Kaushik. (1999) “Child Labor: Cause, Consequence, and Cure,” Journal of Economic Literature, Vol. 37, n. 3, pp. 1083-1119.

Basu, Kaushik, and Zafiris Tzannatos. (2003) "The Global Child Labor Problem: What do We Know and What Can we Do?” World Bank Economic Review, Vol. 17, n. 2, pp. 147-173.

Basu, Kaushik and Pham Hoang Van. (1998) "The Economics of Child Labor," American Economic Review, Vol. 88, n. 3, pp. 412-427.

Becker, Gary S., and Barry R. Chiswick. (1966) "Education and the Distribution of Earnings,” American Economic Review, Vol. 56, no. 1 / 2, pp. 358-369.

Beegle, Kathleen, Rajeev Dehejia, and Roberta Gatti. (2004) "Why Should We Care About Child Labor? The Returns to Schooling vs. the Returns to Experience in Vietnam" National Bureau of Economic Research Working Paper No. 10980.

Black, Sandra E., Paul J. Devereux, and Kjell G. Salvanes. (2005) "Why the Apple Doesn’t Fall Far: Understanding Intergenerational Transmission of Human Capital," American Economic Review, vol. 95, no. 1, pp. 437-449.

Birdsall, N., and R. H. Sabot, eds. (1996). Opportunity Forgone. Education in Brazil. IADB: Washington, DC.

Blau, David M. (1999) “The Effect of Income on Child Development,” The Review of Economics and Statistics, Vol. 81, n. 2., pp. 261-276.

Cameron, Stephen V., and Christopher Taber. (2004) "Estimation of Educational Borrowing Constraints Using Returns to Schooling,” Journal of Political Economy, Vol. 112, n. 1, pt. 1, pp. 132-182.

Card, David. (2001) "Estimating the Returns to Schooling: Progress on Some Persistent Econometric Problems,” Econometrica, Vol. 69, pp. 1127-1160. . (1999) “The Causal Effect of Education on Earnings.” The Handbook of Labor Economics, Orley Ashenfelter and David Card, eds. (New York: Elsevier). . (1995a) "Earnings, Schooling and Ability Revisited," Research in Labor Economics, Vol. 14, n. 1, pp. 23-48.

. (1995b) "Using Geographic Variation in College Proximity to Estimate the Return to Schooling.” Aspects of Labour Market Behavior: Essays in Honor of John Vanderkamp, Louis N. Christofides, E. Kenneth Grant, and Robert Swidinsky, eds. (Toronto: University of Toronto Press).

Carneiro, Pedro, and James J. Heckman. (2002) “The Evidence on Credit Constraints in PostSecondary Schooling,” The Economic Journal, Vol. 112, pp. 705-734.

Chiswick, Barry R. (1974) Income Inequality: Regional Analyses Within a Human Capital Framework. (New York: Columbia University Press for NBER). 
Duflo, Esther (2004) “The Medium Run Consequences of Educational Expansion: Evidence from a Large School Construction Program in Indonesia,” Journal of Development Economics, Vol. 74, No. 1, pp. 163- 197. . (2001) "Schooling and Labor Market Consequences of School Construction in Indonesia: Evidence from an Unusual Policy Experiment,” American Economic Review, Vol. 91, No. 4, pp. 795-813.

Dessy, Sylvain. (2000) “A Defense of Compulsive Measures against Child Labor,” Jounal of Development Economics, Vol. 62, n.1, pp. 261-275.

Dessy, Sylvain and Stephane Pallage. (2001) "Child Labor and Coordination Failures," Journal of Development Economics, Vol. 65, n. 2, pp. 469-476.

Duryea, Suzanne. (1998) "Children's Advancement Through School in Brazil: The Role of Transitory Shocks to Household Income,” Inter-American Development Bank Working Paper 376.

Edmonds, Eric V., and Nina Pavcnik. (2005) “Child Labor in the Global Economy,” Journal of Economic Perspectives, Vol. 19, n. 1, pp. 199-220.

Emerson, Patrick M., and Shawn D. Knabb. (2004) "Fiscal Policy, Expectation Traps and Child Labor," forthcoming, Economic Inquiry. . (2005) "Self-Fulfilling Expectations, Child Labor and Economic Development," Mimeo, University of Colorado at Denver. . (2006) "Opportunity, Inequality and the Intergenerational Transmission of Child Labor,” Economica, Vol. 73, No. 291, pp. 413-434..

Emerson, Patrick M., and André Portela Souza. (2003) "Is there a Child Labor Trap? InterGenerational Persistence of Child Labor in Brazil," Economic Development and Cultural Change, Vol. 51, n. 2, pp. 375 - 398. . (2002) "From Childhood to Adulthood: The Effect of Child Labor Activities on Adult Earnings in Brazil," Mimeo, University of Colorado at Denver.

French, J. Lawrence. (2002) "Adolescent Workers in Third World Export Industries: Attitudes of Young Brazilian Shoemakers," Industrial and Labor Relations Review, Vol. 55, n. 2, pp. 308-323.

Griliches, Zvi. (1977) "Estimating the Returns to Schooling: Some Econometric Problems," Econometrica, Vol 45, n. 1, pp. 1-22.

Horn, Pamela. (1994) Children's Work and Welfare, 1780-1890. (Cambridge: Cambridge University Press).

Horowitz, Andrew, and Jian Wang. (2004) "Favorite Son? Specialized Child Laborers and Students in Poor LDC Households,” Journal of Development Economics, Vol. 73, n. 2, pp. 631-42.

Ilahi, Nadeem, Peter Orazem and Guilherme Sedlacek. (2001) "The Implications of Child Labor for Adult Wages, Income and Poverty: Retrospective Evidence from Brazil,” Mimeo, Iowa State University.

Instituto Brasileiro de Geografia Estatística, (IBGE), (2003). Estatísticas do Século XX. Rio de Janeiro: IBGE.

Instituto Brasileiro de Geografia Estatística, (IBGE). Censo Demográfico. Rio de Janeiro: IBGE. Various years.

International Labor Organization, ILO. (1996) “Economically Active Population 19502010”, (Fourth edition), ILO Publications, Genveva. 
Kassouf, Ana Lúcia, Martin McKee, and Elias Mossialos (2001) "Early Entrance to the Job Market and its Effect on Adult Health: Evidence from Brazil,” Health Policy and Planning, Vol. 16, n. 1, pp. 21-28.

Keane, Michael P., and Kenneth I. Wolpin (2001) “The Effect of Parental Transfers and Borrowing Constraints on Educational Attainment,” International Economic Review, Vol. 42, n. 4, pp. 1051-1103.

Kruse, Douglas L. and Douglas Mahony. (2000) "Illegal Child Labor in the United States: Prevalence and Characteristics,” Industrial and Labor Relations Review, v. 54, n. 1, pp. 17-40.

Lam, David and Suzanne Duryea. (1999) "Effects of Schooling on Fertility, Labor Supply, and Investments in Children, With Evidence from Brazil,” Journal of Human Resources, Vol. 34, n. 1, pp. 160-92.

Lam, David and Robert F. Schoeni. (1993) "Effects of Family Background on Earnings and Returns to Schooling: Evidence from Brazil,” Journal of Political Economy, Vol. 101, n. 4, pp. 710-740.

Manacorda, Marco. (2006) "Child Labor and the Supply of Other Household Members: Evidence from 1920 America,” American Economic Review, Vol. 96, n. 5, pp. 17881801.

Maurin, Eric. (2002) “The Impact of Parental Income on Early Schooling Transitions: A Reexamination Using Data Over Three Generations,” Journal of Public Economics, Vol. 85, n. 3, pp. 301-332.

Mincer, Jacob. (1974) Schooling, Experience and Earnings. (New York: Columbia University Press for NBER).

Neri, M., Emily Gustafsson-Wright, Guilherme Sedlacek, Daniela Ribeiro da Costa \& Alexandre Pinto (2000) "Microeconomic Instability and Children's Human Capital Accumulation: The Effects of Idiosyncratic Shocks to Father's Income on Child Labor, School Drop-Outs and Repetition Rates in Brazil,” Ensaios Econômicos, EPGE, 394, Getulio Vargas Foundation, Brazil

Orazem, Peter F., and Chanyoung Lee (2007) "Lifetime Health Consequences of Child Labor in Brazil," Mimeo.

Parsons, Donald O. and Claudia Goldin. (1989) "Parental Altruism and Self-Interest: Child Labor Among Late Nineteenth-Century American Families”, Economic Inquiry, Vol. 27, n. 4, pp. 637-659.

Plank, David N. (1996) The Means of Our Salvation. Public Education in Brazil, 1930-1995. (Boulder, Colorado: WestviewPress).

Psacharopolous, George (1997), "Child Labor versus Educational Attainment: Some Evidence from Latin America”, Journal of Population Economics, v. 10, October.

Shea, John. (2000) “Does Parents’ Money Matter?”, Journal of Public Economics, v. 77, pp. 155-184

Spindel, Cheywa R. (1985) O Menor Trabalhador: Um Assalariado Registrado. São Paulo: Noel. 

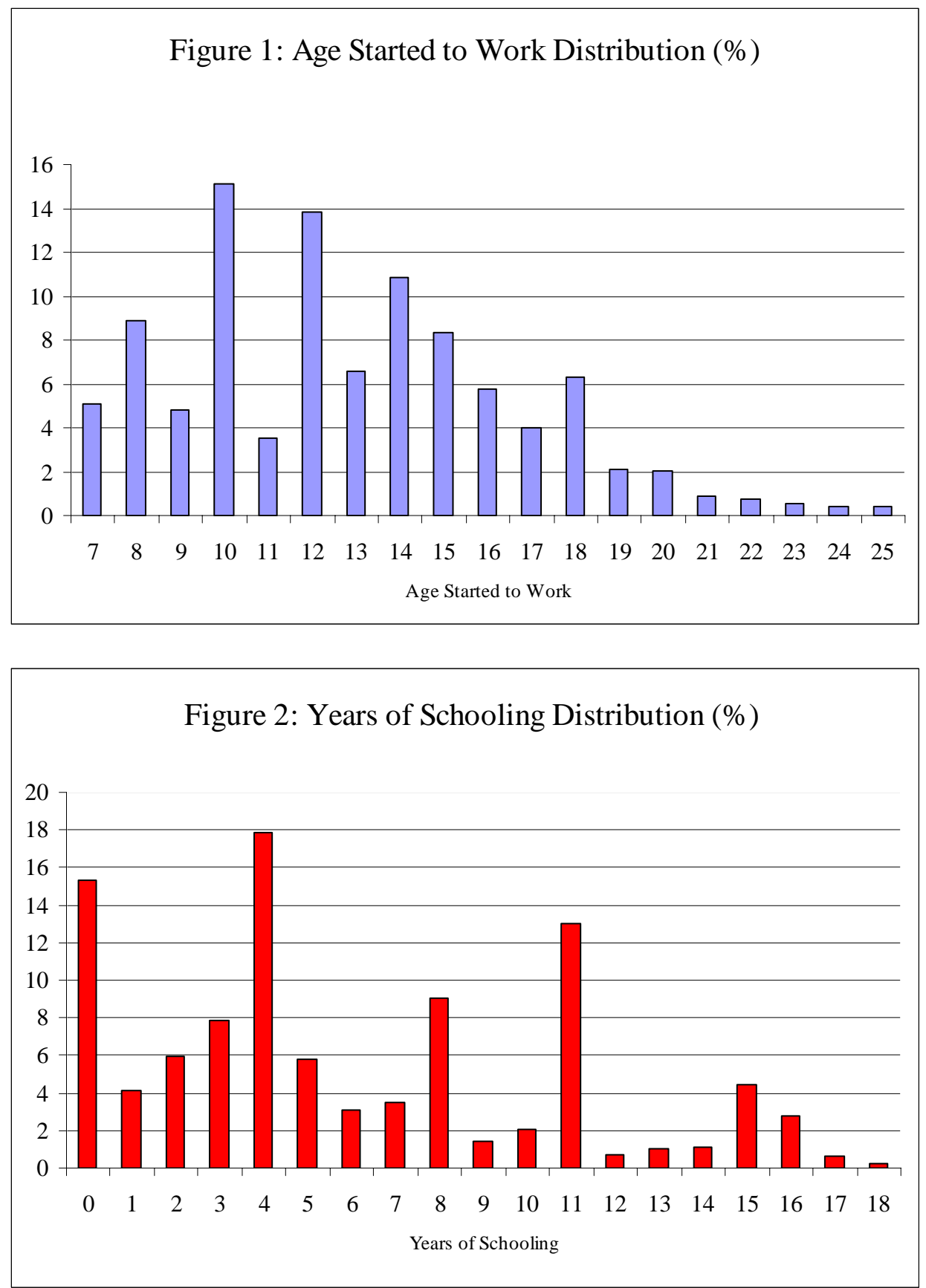

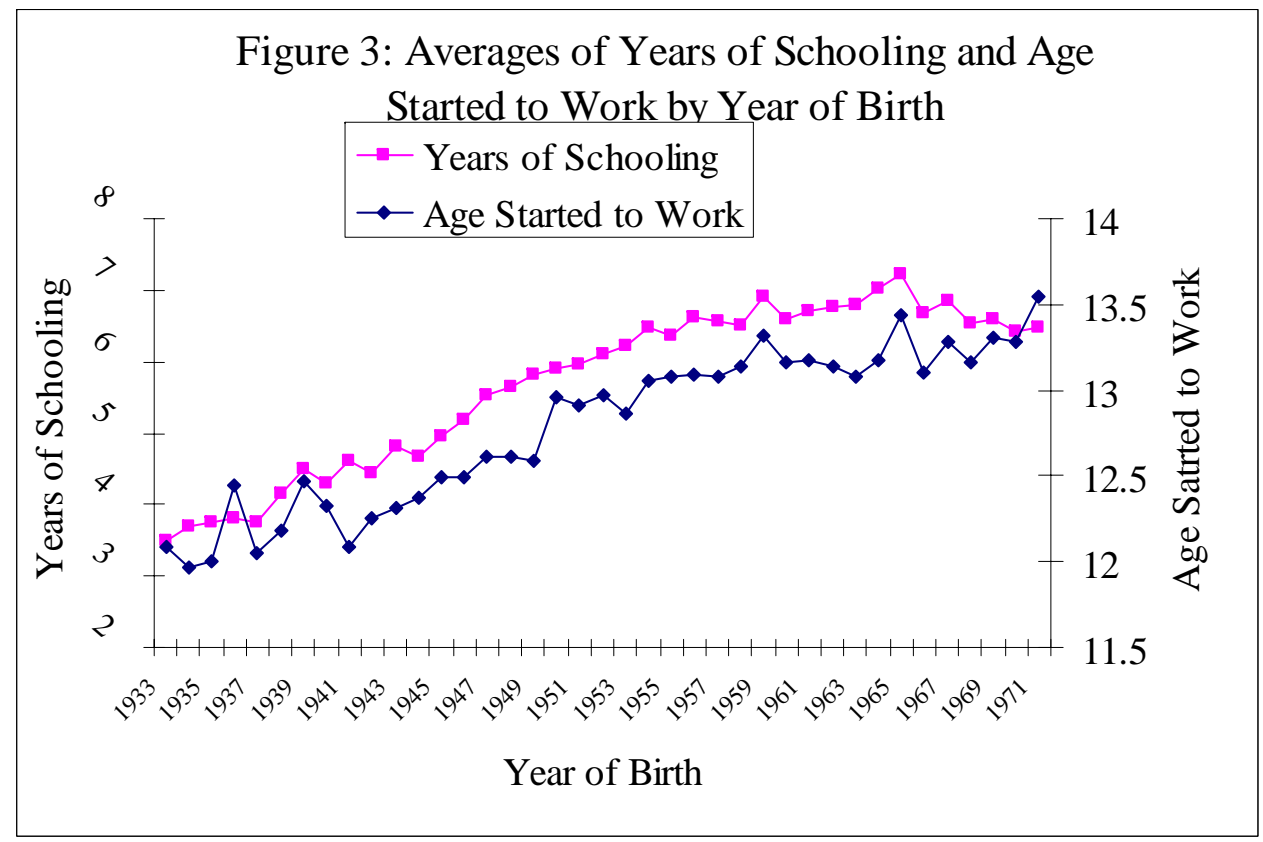

Figure 4: Averages of Log-Earnings and Years of Schooling by Age Started to Work

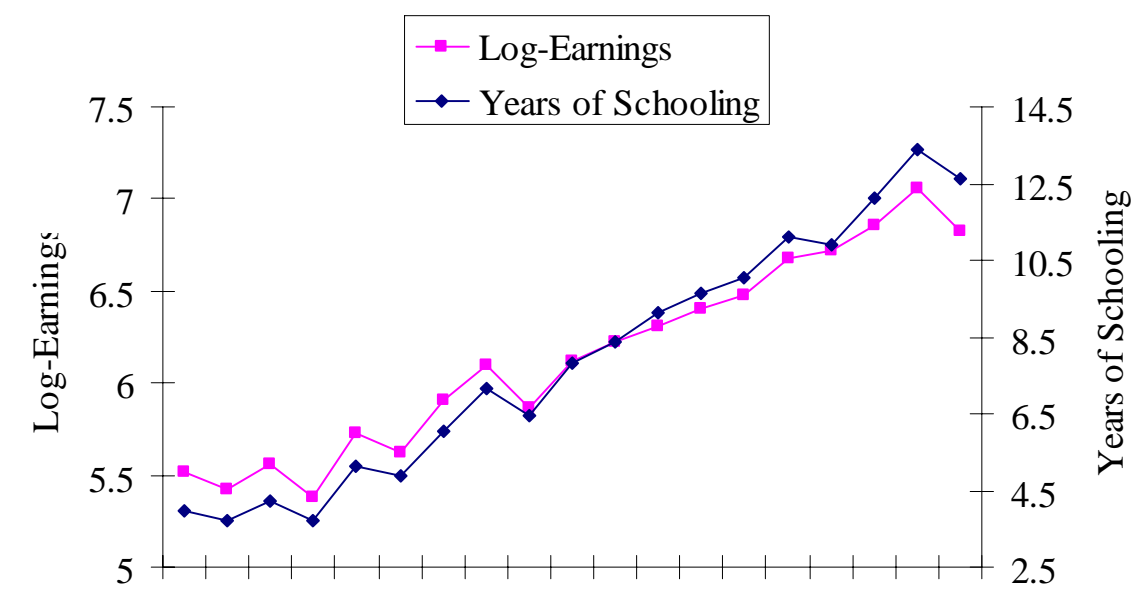

78910111213141516171819202122232425 Age Started to Work 

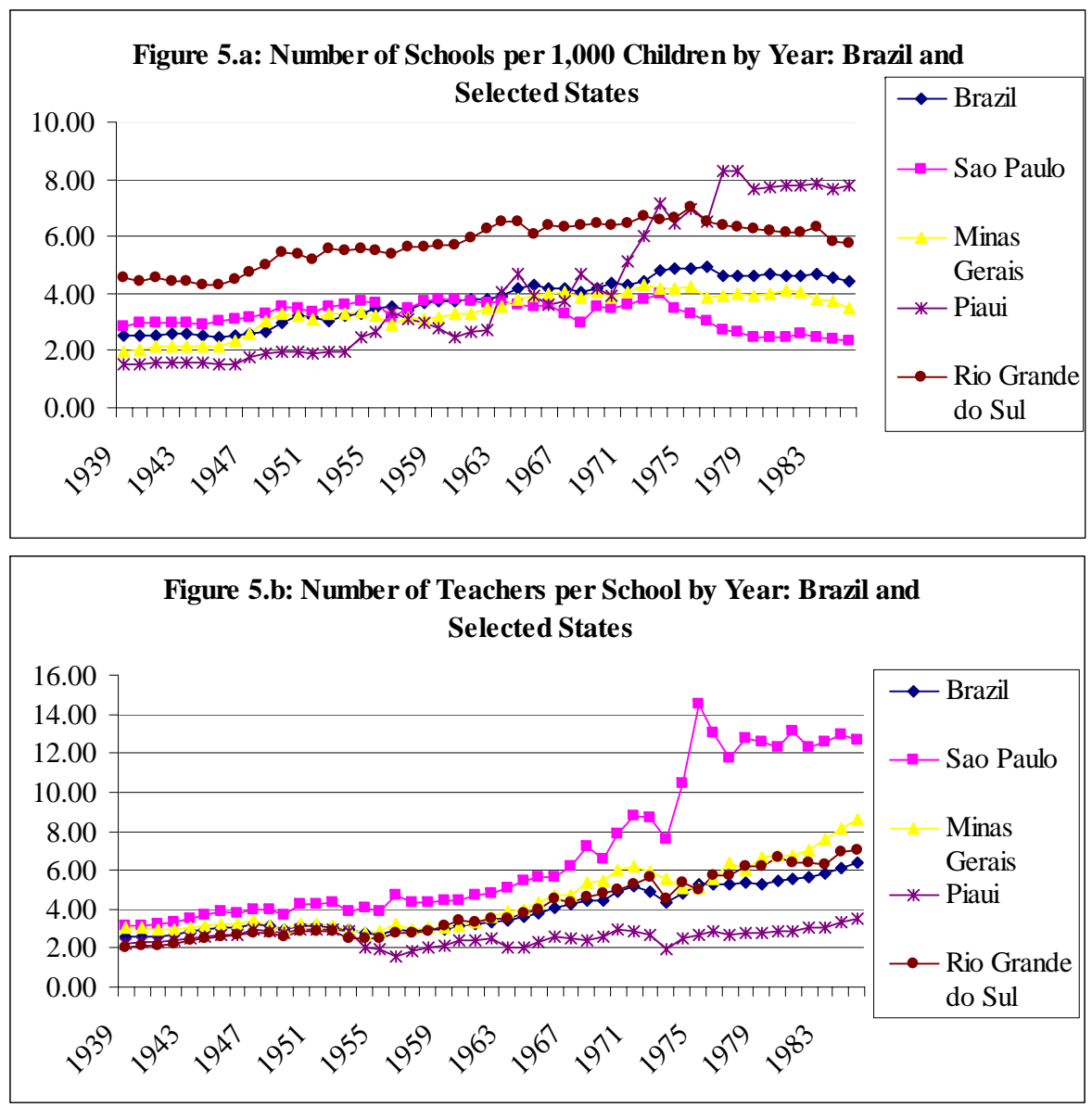

Figure 5.c: GDP per Capita by Year: Brazil and Selected States (Reals of 2000)

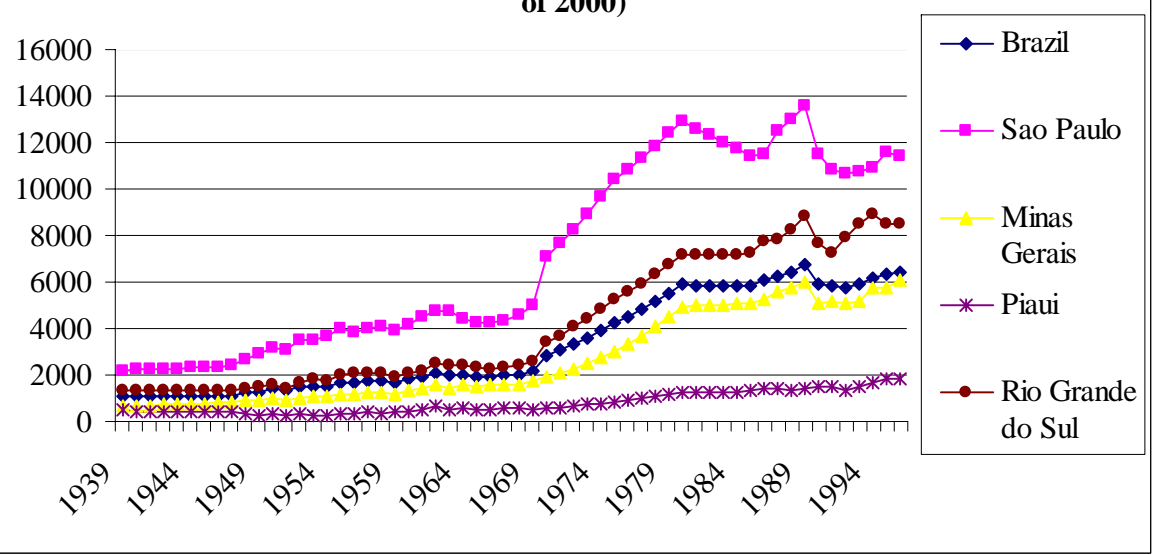

\section{Figure 6:}

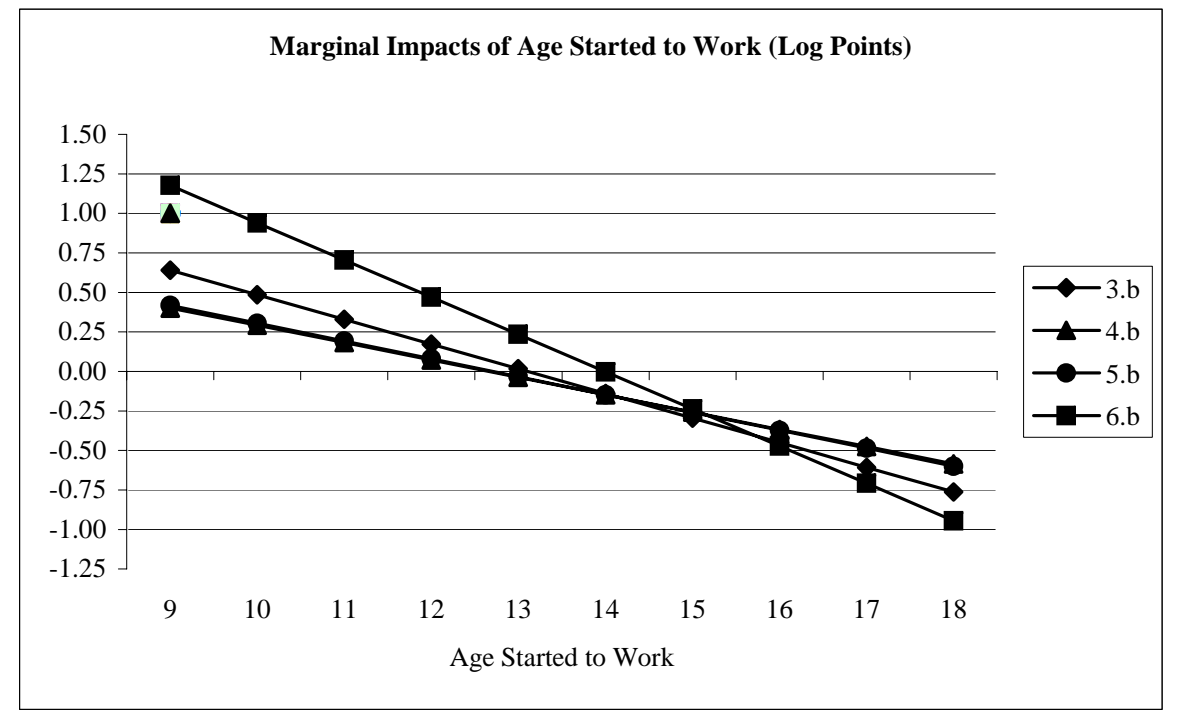

\section{Figure 7:}

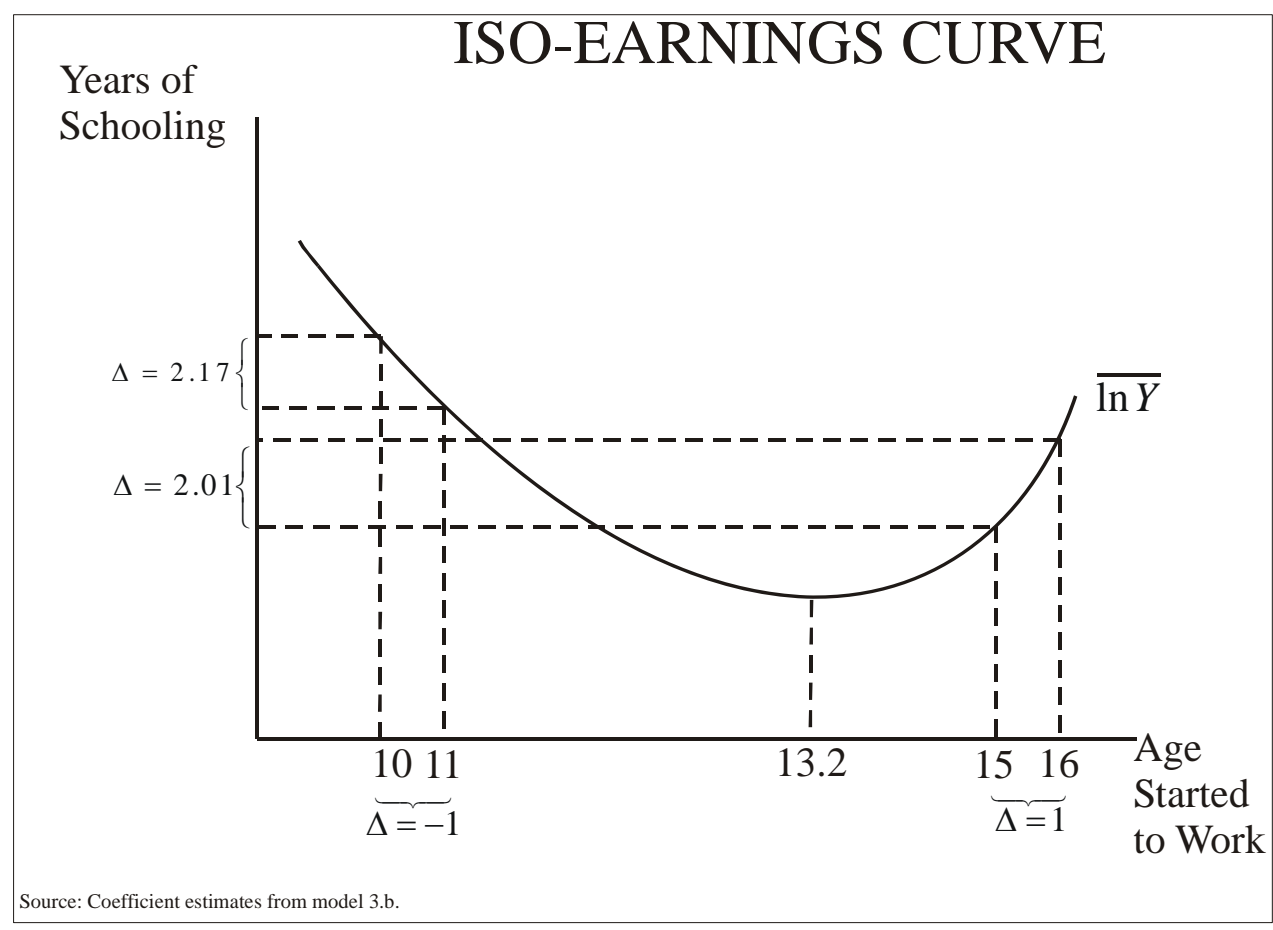


Table 1: Male Child Labor Incidence: Contemporaneous and Retrospective Information

ILO versus 1988 and 1996 PNADs (\%)

\begin{tabular}{|c|c|c|c|c|c|c|c|c|c|c|}
\hline \multirow[t]{2}{*}{ Age } & \multicolumn{2}{|c|}{1950} & \multicolumn{2}{|c|}{1960} & \multicolumn{2}{|c|}{1970} & \multicolumn{2}{|c|}{1980} & \multicolumn{2}{|c|}{1990} \\
\hline & ILO & PNAD & ILO & PNAD & ILO & PNAD & ILO & PNAD & ILO & PNAD \\
\hline & \multicolumn{10}{|c|}{1988 PNAD } \\
\hline 10 to 14 & 34.78 & 46.42 & 32.43 & 44.91 & 29.13 & 31.93 & & & & \\
\hline 15 to 19 & & & 81.24 & 77.99 & 77.68 & 70.60 & & & & \\
\hline \multirow[t]{2}{*}{20 to 24} & & & 94.27 & 84.49 & 93.52 & 86.84 & 92.97 & 70.26 & & \\
\hline & \multicolumn{10}{|c|}{1996 PNAD } \\
\hline 10 to 14 & & & 32.43 & 49.76 & 29.13 & 44.96 & 26.78 & 39.28 & & \\
\hline 15 to 19 & & & 81.24 & 76.03 & 77.68 & 81.64 & 75.14 & 80.62 & & \\
\hline 20 to 24 & & & & & 93.52 & 90.49 & 92.97 & 93.84 & 92.23 & 91.99 \\
\hline
\end{tabular}

Table 2: OLS of Logarithim of Earnings

\begin{tabular}{|c|c|c|c|c|}
\hline \multirow[b]{2}{*}{ Variables } & \multicolumn{2}{|c|}{$\underline{\text { 2.a }}$} & \multicolumn{2}{|c|}{$\underline{2 . \mathbf{b}}$} \\
\hline & Coeff. & Std. Error & Coeff. & Std. Error \\
\hline Years of Schooling & & & 0.1072 & 0.0010 \\
\hline Age Started to Work & 0.0117 & 0.0056 & 0.0122 & 0.0050 \\
\hline Age Started to Work Squared & 0.0010 & 0.0002 & -0.0001 & 0.0002 \\
\hline Age & 0.0879 & 0.0048 & 0.0725 & 0.0043 \\
\hline Age Squared & -0.0010 & 0.0001 & -0.0008 & 0.0001 \\
\hline Black & -0.3582 & 0.0145 & -0.2310 & 0.0132 \\
\hline Pardo & -0.2744 & 0.0080 & -0.1792 & 0.0073 \\
\hline \multicolumn{5}{|l|}{ Father's Education } \\
\hline Some or Completed Lower Primary & 0.2316 & 0.0086 & 0.0652 & 0.0080 \\
\hline Some or Completed Upper Primary & 0.4398 & 0.0195 & 0.1084 & 0.0176 \\
\hline Some or Completed High School & 0.6131 & 0.0226 & 0.1892 & 0.0207 \\
\hline Some or Completed College & 0.8004 & 0.0273 & 0.3207 & 0.0255 \\
\hline \multicolumn{5}{|l|}{ Mother's Education } \\
\hline Some or Completed Lower Primary & 0.2734 & 0.0084 & 0.0998 & 0.0078 \\
\hline Some or Completed Upper Primary & 0.5169 & 0.0197 & 0.1888 & 0.0179 \\
\hline Some or Completed High School & 0.7003 & 0.0222 & 0.2924 & 0.0208 \\
\hline Some or Completed College & 0.7093 & 0.0369 & 0.2903 & 0.0340 \\
\hline \multicolumn{5}{|l|}{ Other Indicator Variables } \\
\hline Rural Area & -0.6307 & 0.0090 & -0.4122 & 0.0086 \\
\hline 1933 to 1958 Birth Year Cohort & 0.0918 & 0.0123 & 0.0709 & 0.0112 \\
\hline 1988 Year & -0.3847 & 0.0081 & -0.3208 & 0.0073 \\
\hline \multicolumn{5}{|l|}{ Great Regions } \\
\hline North & -0.0824 & 0.0165 & -0.0585 & 0.0151 \\
\hline Northeast & -0.2225 & 0.0095 & -0.1682 & 0.0087 \\
\hline South & 0.1953 & 0.0087 & 0.1527 & 0.0078 \\
\hline Center-West & 0.1113 & 0.0143 & 0.0659 & 0.0129 \\
\hline Intercept & 3.7185 & 0.1001 & 3.5946 & 0.0913 \\
\hline R-Squared & 0.400 & & 0.509 & \\
\hline Number of Observations & 62,736 & & 62,575 & \\
\hline Earnings is maximized at Age to Work & & & & \\
\hline
\end{tabular}

Note: White-Huber robust standard errors were computed. 
Table 3: IV Estimates - Second Stage Regression of Logarithm of Earnings

\begin{tabular}{|c|c|c|c|c|}
\hline \multirow[b]{2}{*}{ Variables } & \multicolumn{2}{|c|}{ 3.a } & \multicolumn{2}{|c|}{$\underline{3 . \mathbf{b}}$} \\
\hline & Coeff. & Std. Error & Coeff. & Std. Error \\
\hline Years of Schooling & & & 0.134 & 0.059 \\
\hline Age Started to Work & 1.964 & 0.413 & 1.467 & 0.416 \\
\hline Age Started to Work Squared & -0.070 & 0.016 & -0.056 & 0.015 \\
\hline Age & 0.121 & 0.012 & 0.096 & 0.016 \\
\hline Age Squared & -0.001 & 0.000 & -0.001 & 0.000 \\
\hline Black & -0.473 & 0.036 & -0.287 & 0.089 \\
\hline Pardo & -0.353 & 0.025 & -0.225 & 0.061 \\
\hline \multicolumn{5}{|l|}{ Father's Education } \\
\hline Some or Completed Lower Primary & 0.177 & 0.027 & 0.028 & 0.070 \\
\hline Some or Completed Upper Primary & 0.480 & 0.095 & 0.185 & 0.153 \\
\hline Some or Completed High School & 0.826 & 0.142 & 0.413 & 0.218 \\
\hline Some or Completed College & 1.552 & 0.291 & 1.033 & 0.344 \\
\hline \multicolumn{5}{|l|}{ Mother's Education } \\
\hline Some or Completed Lower Primary & 0.244 & 0.031 & 0.081 & 0.076 \\
\hline Some or Completed Upper Primary & 0.615 & 0.091 & 0.284 & 0.166 \\
\hline Some or Completed High School & 1.023 & 0.154 & 0.591 & 0.236 \\
\hline Some or Completed College & 1.091 & 0.185 & 0.643 & 0.254 \\
\hline \multicolumn{5}{|l|}{ Other Indicator Variables } \\
\hline Rural Area & -0.523 & 0.050 & -0.368 & 0.079 \\
\hline 1933 to 1958 Birth Year Cohort & 0.135 & 0.031 & 0.105 & 0.028 \\
\hline 1988 Year & -0.366 & 0.019 & -0.281 & 0.038 \\
\hline \multicolumn{5}{|l|}{ Great Regions } \\
\hline North & -0.137 & 0.034 & -0.080 & 0.039 \\
\hline Northeast & -0.171 & 0.023 & -0.109 & 0.032 \\
\hline South & 0.099 & 0.044 & 0.037 & 0.046 \\
\hline Center-West & 0.133 & 0.038 & 0.025 & 0.055 \\
\hline Intercept & -9.394 & 2.674 & -5.860 & 2.782 \\
\hline Number of Observations & 62,736 & & 62,575 & \\
\hline \multicolumn{5}{|l|}{ Overidentification Test of All Instruments } \\
\hline Hansen J-Sattistic Chi-Square & 5.877 & & 5.758 & \\
\hline P-value (Degrees of Freedom) & 0.318 & (5) & 0.218 & (4) \\
\hline Earnings is Maximized at Age to Work & 14.01 & 0.32 & 13.18 & 0.50 \\
\hline
\end{tabular}

Note: Clustered standard errors by birth year and birth state. 
Table 4: Alternative Specification of IV Estimates - Second Stage Regression of Logarithm of Earnings with Labor Market Control

\begin{tabular}{|c|c|c|c|c|}
\hline \multirow[b]{2}{*}{ Variables } & \multicolumn{2}{|c|}{ 4.a } & \multicolumn{2}{|c|}{ 4.b } \\
\hline & Coeff. & Std. Error & Coeff. & Std. Error \\
\hline Years of Schooling & & & 0.125 & 0.057 \\
\hline Age Started to Work & 0.793 & 0.392 & 1.011 & 0.372 \\
\hline Age Started to Work Squared & -0.034 & 0.014 & -0.041 & 0.014 \\
\hline Age & 0.102 & 0.010 & 0.090 & 0.012 \\
\hline Age Squared & -0.001 & 0.000 & -0.001 & 0.000 \\
\hline Black & -0.409 & 0.029 & -0.272 & 0.068 \\
\hline Pardo & -0.327 & 0.020 & -0.221 & 0.051 \\
\hline \multicolumn{5}{|l|}{ Father's Education } \\
\hline Some or Completed Lower Primary & 0.327 & 0.030 & 0.098 & 0.107 \\
\hline Some or Completed Upper Primary & 0.802 & 0.088 & 0.333 & 0.224 \\
\hline Some or Completed High School & 1.162 & 0.124 & 0.572 & 0.284 \\
\hline Some or Completed College & 1.802 & 0.239 & 1.160 & 0.359 \\
\hline \multicolumn{5}{|l|}{ Mother's Education } \\
\hline Some or Completed Lower Primary & 0.393 & 0.034 & 0.152 & 0.113 \\
\hline Some or Completed Upper Primary & 0.848 & 0.082 & 0.397 & 0.214 \\
\hline Some or Completed High School & 1.256 & 0.127 & 0.710 & 0.273 \\
\hline Some or Completed College & 1.285 & 0.155 & 0.744 & 0.279 \\
\hline \multicolumn{5}{|l|}{ Other Indicator Variables } \\
\hline Rural Area & -0.829 & 0.060 & -0.501 & 0.156 \\
\hline 1933 to 1958 Birth Year Cohort & 0.119 & 0.026 & 0.101 & 0.024 \\
\hline 1988 Year & -0.310 & 0.017 & -0.264 & 0.025 \\
\hline State GDP Per Capita at Age 25 & 0.041 & 0.007 & 0.017 & 0.013 \\
\hline \multicolumn{5}{|l|}{ Great Regions } \\
\hline North & -0.015 & 0.033 & -0.034 & 0.032 \\
\hline Northeast & -0.101 & 0.022 & -0.087 & 0.021 \\
\hline South & -0.037 & 0.041 & -0.015 & 0.039 \\
\hline Center-West & 0.033 & 0.032 & -0.008 & 0.035 \\
\hline Intercept & -0.770 & 2.610 & -2.509 & 2.519 \\
\hline Number of Observations & 62,736 & & 62,575 & \\
\hline \multicolumn{5}{|c|}{ Overidentification Test of All Instruments } \\
\hline Hansen J-Sattistic Chi-Square & 9.16 & & 7.261 & \\
\hline P-value (Degrees of Freedom) & 0.103 & & 0.123 & \\
\hline
\end{tabular}

Test of Excluded Instruments in the First Satge Regressions

Years of Schooling

$\underline{F(7,916)}$ Partial R-2 F(7,916) Partial R-2

$\begin{array}{lllll}\text { Age Started to Work } & 10.14 & 0.0017 & 9.94 & 0.0007\end{array}$

\begin{tabular}{lrrrr} 
Age Started to Work Squared & 9.51 & 0.0016 & 9.34 & 0.0007 \\
\hline
\end{tabular}

\begin{tabular}{lllll}
\hline Earnings is Maximized at Age At Work & 11.71 & 0.96 & 12.23 & 0.63 \\
\hline
\end{tabular}

Note: Clustered standard errors by birth year and birth state. 
Table 5: Alternative Specification of IV Estimates - Second Stage Regression of Logarithm of Earnings with Labor Market and Migration Controls

\begin{tabular}{|c|c|c|c|c|}
\hline \multirow[b]{2}{*}{ Variables } & \multicolumn{2}{|c|}{$\underline{5 . a}$} & \multicolumn{2}{|c|}{$\underline{5 . b}$} \\
\hline & Coeff. & Std. Error & Coeff. & Std. Error \\
\hline Years of Schooling & & & 0.192 & 0.067 \\
\hline Age Started to Work & 0.819 & 0.403 & 1.050 & 0.359 \\
\hline Age Started to Work Squared & -0.035 & 0.015 & -0.040 & 0.013 \\
\hline Migrant & 0.066 & 0.161 & -0.217 & 0.183 \\
\hline Age & 0.104 & 0.011 & 0.079 & 0.014 \\
\hline Age Squared & -0.001 & 0.000 & -0.001 & 0.000 \\
\hline Black & -0.408 & 0.030 & -0.204 & 0.077 \\
\hline Pardo & -0.326 & 0.021 & -0.167 & 0.059 \\
\hline \multicolumn{5}{|l|}{ Father's Education } \\
\hline Some or Completed Lower Primary & 0.337 & 0.039 & -0.061 & 0.145 \\
\hline Some or Completed Upper Primary & 0.834 & 0.119 & -0.032 & 0.326 \\
\hline Some or Completed High School & 1.206 & 0.162 & 0.109 & 0.413 \\
\hline Some or Completed College & 1.876 & 0.298 & 0.563 & 0.544 \\
\hline \multicolumn{5}{|l|}{ Mother's Education } \\
\hline Some or Completed Lower Primary & 0.405 & 0.045 & -0.018 & 0.156 \\
\hline Some or Completed Upper Primary & 0.875 & 0.106 & 0.059 & 0.306 \\
\hline Some or Completed High School & 1.299 & 0.164 & 0.265 & 0.403 \\
\hline Some or Completed College & 1.332 & 0.195 & 0.288 & 0.414 \\
\hline \multicolumn{5}{|l|}{ Others } \\
\hline \multicolumn{5}{|l|}{ Other Indicator Variables } \\
\hline Rural Area & -0.842 & 0.069 & -0.279 & 0.207 \\
\hline 1933 to 1958 Birth Year Cohort & 0.119 & 0.026 & 0.089 & 0.025 \\
\hline 1988 Year & -0.325 & 0.044 & -0.189 & 0.064 \\
\hline State GDP Per Capita at Age 25 & 0.043 & 0.007 & -0.001 & 0.017 \\
\hline \multicolumn{5}{|l|}{ Great Regions } \\
\hline North & 0.003 & 0.056 & -0.103 & 0.063 \\
\hline Northeast & -0.097 & 0.024 & -0.095 & 0.023 \\
\hline South & -0.067 & 0.084 & 0.096 & 0.097 \\
\hline Center-West & 0.031 & 0.033 & -0.023 & 0.036 \\
\hline Intercept & -0.887 & 2.675 & -3.137 & 2.436 \\
\hline Number of Observations & 62,736 & & 62,575 & \\
\hline \multicolumn{5}{|c|}{ Overidentification Test of All Instruments } \\
\hline Hansen J-Sattistic Chi-Square & 8.474 & & 5.870 & \\
\hline P-value (Degrees of Freedom) & 0.076 & & 0.118 & \\
\hline
\end{tabular}

Test of Excluded Instruments in the First Satge Regressions

Years of Schooling

$\underline{F(7,916)}$ Partial R-2 $\underline{F(7,916)}$ Partial R-2

Age Started to Work

$5.14 \quad 0.0008$

Age Started to Work Squared

$\begin{array}{llll}10.14 & 0.0017 & 9.94 & 0.0016\end{array}$

Migrant

$\begin{array}{llll}9.51 & 0.0016 & 9.34 & 0.0015\end{array}$

Earnings is Maximized at Age At Work

16.66 0.0125

$16.42 \quad 0.0125$

Note: Clustered standard errors by birth year and birth state. 
Table 6: Alternative Specification of IV Estimates - Second Stage Regression of Logarithm of Earnings with Labor Market, Migration, and School Quality Controls

\begin{tabular}{|c|c|c|c|c|}
\hline \multirow[b]{2}{*}{ Variables } & \multicolumn{2}{|c|}{$\underline{6 . a}$} & \multicolumn{2}{|c|}{$\underline{6 . b}$} \\
\hline & Coeff. & Std. Error & Coeff. & Std. Error \\
\hline Years of Schooling & & & 0.170 & 0.159 \\
\hline Age Started to Work & 2.085 & 1.000 & 2.489 & 1.200 \\
\hline Age Started to Work Squared & -0.075 & 0.033 & -0.086 & 0.039 \\
\hline Migrant & 0.085 & 0.224 & -0.136 & 0.309 \\
\hline Age & 0.119 & 0.017 & 0.100 & 0.027 \\
\hline Age Squared & -0.001 & 0.000 & -0.001 & 0.000 \\
\hline Black & -0.477 & 0.059 & -0.305 & 0.176 \\
\hline Pardo & -0.356 & 0.032 & -0.215 & 0.137 \\
\hline \multicolumn{5}{|l|}{ Father's Education } \\
\hline Some or Completed Lower Primary & 0.185 & 0.113 & -0.190 & 0.372 \\
\hline Some or Completed Upper Primary & 0.523 & 0.257 & -0.299 & 0.820 \\
\hline Some or Completed High School & 0.892 & 0.294 & -0.137 & 1.007 \\
\hline Some or Completed College & 1.684 & 0.391 & 0.480 & 1.204 \\
\hline \multicolumn{5}{|l|}{ Mother's Education } \\
\hline Some or Completed Lower Primary & 0.253 & 0.118 & -0.149 & 0.397 \\
\hline Some or Completed Upper Primary & 0.652 & 0.201 & -0.111 & 0.744 \\
\hline Some or Completed High School & 1.095 & 0.250 & 0.139 & 0.935 \\
\hline Some or Completed College & 1.172 & 0.268 & 0.216 & 0.944 \\
\hline \multicolumn{5}{|l|}{ Others } \\
\hline \multicolumn{5}{|l|}{ Other Indicator Variables } \\
\hline Rural Area & -0.527 & 0.234 & 0.026 & 0.577 \\
\hline 1933 to 1958 Birth Year Cohort & 0.102 & 0.033 & 0.080 & 0.040 \\
\hline 1988 Year & -0.358 & 0.070 & -0.252 & 0.122 \\
\hline State GDP Per Capita at Age 25 & 0.043 & 0.009 & 0.003 & 0.039 \\
\hline Average Teacher per School at Age 7 to 14 & -0.025 & 0.016 & -0.027 & 0.018 \\
\hline \multicolumn{5}{|l|}{ Great Regions } \\
\hline North & -0.117 & 0.100 & -0.222 & 0.147 \\
\hline Northeast & -0.130 & 0.038 & -0.134 & 0.045 \\
\hline South & -0.038 & 0.104 & 0.115 & 0.179 \\
\hline Center-West & 0.157 & 0.101 & 0.134 & 0.120 \\
\hline Intercept & -10.191 & 7.152 & -13.646 & 8.781 \\
\hline Number of Observations & 62,736 & & 62,575 & \\
\hline \multicolumn{5}{|c|}{ Overidentification Test of All Instruments } \\
\hline Hansen J-Sattistic Chi-Square & 1.576 & & & \\
\hline P-value (Degrees of Freedom) & 0.209 & & & \\
\hline
\end{tabular}

Test of Excluded Instruments in the First Satge Regressions

Years of Schooling

$\underline{\mathrm{F}(4,916)}$ Partial R-2 $\underline{\mathrm{F}(4,916)}$ Partial R-2

Age Started to Work

Age Started to Work Squared

$5.65 \quad 0.0006$

$4.92 \quad 0.0004$

Migrant

$\begin{array}{llll}7.01 & 0.0007 & 6.96 & 0.0007\end{array}$

Earnings is Maximized at Age At Work

$\begin{array}{llll}12.49 & 0.0077 & 12.34 & 0.0076\end{array}$

Note: Clustered standard errors by birth year and birth state; (ii) The intruments are number of school at ages 7, 11, and 15, and the state GDP percapita at age 12 . 
Table 7: Age Started to Work Turning Point

\begin{tabular}{lcccc}
\hline Model & Age & Std. Dev. & \multicolumn{2}{c}{ 95\% Conf. Interval } \\
\hline \multirow{4}{*}{ 3.c } & 14.01 & 0.32 & 13.39 & 14.63 \\
4.c & 11.71 & 0.96 & 9.83 & 13.59 \\
5.c & 11.57 & 1.04 & 9.53 & 13.61 \\
6.c & 13.87 & 0.87 & 12.17 & 15.57 \\
& \multicolumn{4}{c}{ Schooling Control } \\
3.d & 13.18 & 0.50 & 12.20 & 14.17 \\
4.d & 12.23 & 0.63 & 11.00 & 13.45 \\
5.d & 12.97 & 0.75 & 11.49 & 14.45 \\
6.d & 14.49 & 0.89 & 12.75 & 16.23 \\
\hline
\end{tabular}

Note: The point estimates are constructed using the coefficients of the variables age started to work and its square. The standard deviations are obtained by the delta-method. 


\section{APPENDICES}

NOTE: APPENDICES ARE INCLUDED FOR REFEREE INSPECTION

AND ARE NOT NECESSARILY INTENDED TO BE INCLUDED IN

PUBLISHED VERSION OF THE PAPER

Appendix A: Tables

Table A.1: The Sample Selection

\begin{tabular}{lccc}
\hline & $\begin{array}{c}\text { Number of } \\
\text { Observations }\end{array}$ & $\begin{array}{c}\text { Percentage in } \\
\text { Relation to all 25 to } \\
\text { 55 Males }\end{array}$ & $\begin{array}{c}\text { Percentage in } \\
\text { Relation to the } \\
\text { Previous Row }\end{array}$ \\
\hline All Males Aged 25 to 55 & 108,229 & 100.00 & 100.00 \\
Participating in the Labor Market & 101,901 & 94.15 & 94.15 \\
Working with Strictly Positive Earnings & 95,337 & 88.09 & 93.56 \\
Head of Household or Spouse Only & 80,587 & 74.46 & 84.53 \\
Age Started to Work Between 7 and 25 & 78,604 & 72.63 & 97.54 \\
Valid Father's Education Information & 65,672 & 60.68 & 83.55 \\
Valid Mother's Education Information & 63,051 & 58.26 & 96.01 \\
Valid Birth State Information & 62,745 & 57.97 & 99.51 \\
\hline
\end{tabular}


Table A.2: Summary Statistics

\begin{tabular}{|c|c|c|c|c|c|}
\hline Variables & Obs & Mean & Std. Dev. & Min & Max \\
\hline Log-Earnings of Main Job & 62,745 & 5.82 & 1.09 & -0.70 & 10.82 \\
\hline Years of Schooling & 62,584 & 5.96 & 4.70 & 0.00 & 18.00 \\
\hline Age Started to Work & 62,745 & 12.87 & 3.75 & 7.00 & 25.00 \\
\hline Age Started to Work Squared & 62,745 & 179.77 & 105.41 & 49.00 & 625.00 \\
\hline Age & 62,745 & 38.29 & 8.12 & 25.00 & 55.00 \\
\hline Age Squared & 62,745 & 1532.34 & 641.10 & 625.00 & 3025.00 \\
\hline Black & 62,736 & 0.05 & 0.23 & 0.00 & 1.00 \\
\hline Pardo & 62,736 & 0.38 & 0.48 & 0.00 & 1.00 \\
\hline \multicolumn{6}{|l|}{ Father's Education } \\
\hline Illiterate & 62,745 & 0.36 & 0.48 & 0.00 & 1.00 \\
\hline Some or Completed Lower Primary & 62,745 & 0.52 & 0.50 & 0.00 & 1.00 \\
\hline Some or Completed Upper Primary & 62,745 & 0.05 & 0.21 & 0.00 & 1.00 \\
\hline Some or Completed High School & 62,745 & 0.04 & 0.19 & 0.00 & 1.00 \\
\hline Some or Completed College & 62,745 & 0.03 & 0.16 & 0.00 & 1.00 \\
\hline \multicolumn{6}{|l|}{ Mother's Education } \\
\hline Illiterate & 62,745 & 0.43 & 0.49 & 0.00 & 1.00 \\
\hline Some or Completed Lower Primary & 62,745 & 0.47 & 0.50 & 0.00 & 1.00 \\
\hline Some or Completed Upper Primary & 62,745 & 0.05 & 0.22 & 0.00 & 1.00 \\
\hline Some or Completed High School & 62,745 & 0.04 & 0.20 & 0.00 & 1.00 \\
\hline Some or Completed College & 62,745 & 0.01 & 0.10 & 0.00 & 1.00 \\
\hline \multicolumn{6}{|l|}{ Other Indicator Variables } \\
\hline Rural Area & 62,745 & 0.21 & 0.41 & 0.00 & 1.00 \\
\hline 1933 to 1958 Birth Year Cohort & 62,745 & 0.68 & 0.47 & 0.00 & 1.00 \\
\hline 1988 Year & 62,745 & 0.50 & 0.50 & 0.00 & 1.00 \\
\hline Migrant & 62,745 & 0.38 & 0.49 & 0.00 & 1.00 \\
\hline \multicolumn{6}{|c|}{ Number of Schools per 1,000 Children by State } \\
\hline At Age 7 & 62,745 & 4.09 & 1.39 & 0.00 & 9.77 \\
\hline At Age 11 & 62,745 & 4.37 & 1.47 & 1.08 & 9.77 \\
\hline At Age 15 & 62,745 & 4.59 & 1.53 & 1.02 & 9.77 \\
\hline \multicolumn{6}{|c|}{ Number of Teachers per School by State } \\
\hline At Age 7 & 62,745 & 3.75 & 2.28 & 0.00 & 25.76 \\
\hline At Age 11 & 62,745 & 4.19 & 2.71 & 1.44 & 27.46 \\
\hline At Age 15 & 62,745 & 4.71 & 3.14 & 1.44 & 27.46 \\
\hline Average Age 7 to 14 & 62,745 & 4.15 & 2.60 & 1.34 & 24.62 \\
\hline \multicolumn{6}{|l|}{ Sate GDP Per Capita } \\
\hline At Age 12 & 62,745 & 2.38 & 1.94 & 0.28 & 11.84 \\
\hline At Age 25 & 62,745 & 4.23 & 2.75 & 0.34 & 12.39 \\
\hline
\end{tabular}


Table A.3: IV Estimates - First Stage Regressions

\begin{tabular}{|c|c|c|c|c|c|c|c|c|c|c|}
\hline \multirow[b]{4}{*}{ Variables } & \multicolumn{4}{|c|}{ 3.a } & \multicolumn{6}{|c|}{ 3.b } \\
\hline & \multirow{2}{*}{\multicolumn{2}{|c|}{$\frac{\text { Age Started to }}{\underline{\text { Work }}}$}} & \multirow{2}{*}{\multicolumn{2}{|c|}{$\frac{\text { Age Started to Work }}{\text { Squared }}$}} & \multirow{2}{*}{\multicolumn{2}{|c|}{ Years of Schooling }} & \multirow{2}{*}{\multicolumn{2}{|c|}{$\frac{\text { Age Started to }}{\text { Work }}$}} & \multirow{2}{*}{\multicolumn{2}{|c|}{$\frac{\text { Age Started to Work }}{\text { Squared }}$}} \\
\hline & & & & & & & & & & \\
\hline & Coeff. & Std. Error & Coeff. & Std. Error & Coeff. & Std. Error & Coeff. & Std. Error & Coeff. & Std. Error \\
\hline Age & 0.017 & 0.024 & 0.929 & 0.677 & 0.136 & 0.025 & 0.018 & 0.024 & 0.953 & 0.681 \\
\hline Age Squared & -0.0004 & 0.0003 & -0.015 & 0.008 & -0.002 & 0.0003 & -0.0004 & 0.0003 & -0.016 & 0.008 \\
\hline Black & 0.048 & 0.058 & -0.247 & 1.575 & -1.209 & 0.058 & 0.049 & 0.058 & -0.215 & 1.574 \\
\hline Pardo & -0.098 & 0.035 & -3.825 & 0.966 & -0.910 & 0.036 & -0.099 & 0.035 & -3.847 & 0.969 \\
\hline \multicolumn{11}{|l|}{ Father's Education } \\
\hline Some or Completed Lower Primary & 0.693 & 0.035 & 18.288 & 0.935 & 1.714 & 0.036 & 0.694 & 0.035 & 18.327 & 0.935 \\
\hline Some or Completed Upper Primary & 1.984 & 0.075 & 55.204 & 2.263 & 3.594 & 0.092 & 1.986 & 0.075 & 55.264 & 2.262 \\
\hline Some or Completed High School & 2.566 & 0.093 & 73.661 & 2.884 & 4.629 & 0.094 & 2.558 & 0.093 & 73.403 & 2.872 \\
\hline Some or Completed College & 3.697 & 0.126 & 112.590 & 4.165 & 5.497 & 0.106 & 3.717 & 0.125 & 113.196 & 4.144 \\
\hline \multicolumn{11}{|l|}{ Mother's Education } \\
\hline Some or Completed Lower Primary & 0.786 & 0.036 & 21.108 & 0.963 & 1.821 & 0.036 & 0.785 & 0.036 & 21.065 & 0.967 \\
\hline Some or Completed Upper Primary & 1.636 & 0.083 & 46.310 & 2.548 & 3.493 & 0.086 & 1.634 & 0.083 & 46.239 & 2.544 \\
\hline Some or Completed High School & 2.276 & 0.101 & 67.162 & 3.147 & 4.418 & 0.097 & 2.285 & 0.101 & 67.448 & 3.147 \\
\hline Some or Completed College & 2.318 & 0.169 & 69.333 & 5.532 & 4.544 & 0.148 & 2.324 & 0.169 & 69.580 & 5.552 \\
\hline \multicolumn{11}{|l|}{ Other Indicator Variables } \\
\hline Rural Area & -1.465 & 0.039 & -38.791 & 1.018 & -2.379 & 0.032 & -1.462 & 0.039 & -38.718 & 1.021 \\
\hline 1933 to 1958 Birth Year Cohort & 0.146 & 0.080 & 4.426 & 2.242 & 0.226 & 0.067 & 0.146 & 0.080 & 4.404 & 2.240 \\
\hline 1988 Year & 0.243 & 0.047 & 7.070 & 1.342 & -0.508 & 0.045 & 0.246 & 0.047 & 7.134 & 1.346 \\
\hline \multicolumn{11}{|l|}{ Great Regions } \\
\hline North & 0.425 & 0.086 & 10.600 & 2.493 & 0.027 & 0.080 & 0.423 & 0.086 & 10.501 & 2.485 \\
\hline Northeast & 0.214 & 0.063 & 6.029 & 1.726 & -0.312 & 0.047 & 0.215 & 0.063 & 6.073 & 1.728 \\
\hline South & -0.606 & 0.081 & -18.084 & 2.221 & 0.275 & 0.071 & -0.602 & 0.081 & -17.941 & 2.222 \\
\hline Center-West & -0.648 & 0.073 & -17.557 & 1.997 & 0.314 & 0.068 & -0.645 & 0.073 & -17.482 & 1.997 \\
\hline \multicolumn{11}{|c|}{ Number of Schools per 1,000 Children by State } \\
\hline At Age 7 & 0.043 & 0.041 & 1.366 & 1.142 & -0.103 & 0.036 & 0.045 & 0.041 & 1.421 & 1.145 \\
\hline At Age 11 & 0.079 & 0.051 & 2.263 & 1.408 & 0.046 & 0.048 & 0.076 & 0.051 & 2.175 & 1.413 \\
\hline At Age 15 & -0.044 & 0.032 & -1.072 & 0.888 & 0.035 & 0.034 & -0.044 & 0.033 & -1.072 & 0.889 \\
\hline \multicolumn{11}{|l|}{ Number of Teachers per School by State } \\
\hline At Age 7 & 0.002 & 0.027 & 0.107 & 0.791 & -0.070 & 0.028 & 0.006 & 0.028 & 0.217 & 0.799 \\
\hline At Age 11 & 0.016 & 0.031 & 0.497 & 0.895 & -0.025 & 0.029 & 0.014 & 0.031 & 0.403 & 0.907 \\
\hline At Age 15 & 0.082 & 0.022 & 2.214 & 0.633 & 0.153 & 0.019 & 0.082 & 0.023 & 2.215 & 0.637 \\
\hline State GDP Per Capita at Age 12 & -0.009 & 0.030 & -0.445 & 0.846 & -0.013 & 0.030 & -0.011 & 0.030 & -0.501 & 0.850 \\
\hline Intercept & 11.112 & 0.539 & 119.398 & 15.104 & 2.403 & 0.527 & 11.115 & 0.542 & 119.149 & 15.197 \\
\hline R-Squared & 0.937 & & 0.794 & & 0.791 & & 0.937 & & 0.794 & \\
\hline Partial R-Squared & 0.0036 & & 0.0031 & & 0.0040 & & 0.0035 & & 0.0031 & \\
\hline Test of Excluded Instruments F(7, 916) & 14.18 & & 12.41 & & 24.94 & & 13.91 & & 12.22 & \\
\hline
\end{tabular}

Note: White-Huber robust standard errors were computed. 
Table A.4: IV Estimates - First Stage Regressions

\begin{tabular}{|c|c|c|c|c|c|c|c|c|c|c|}
\hline \multirow[b]{4}{*}{ Variables } & \multicolumn{4}{|c|}{ 4.a } & \multicolumn{6}{|c|}{ 4.b } \\
\hline & \multirow{2}{*}{\multicolumn{2}{|c|}{$\frac{\text { Age Started to }}{\text { Work }}$}} & \multirow{2}{*}{\multicolumn{2}{|c|}{$\frac{\text { Age Started to }}{\text { Work Squared }}$}} & \multirow{2}{*}{\multicolumn{2}{|c|}{ Years of Schooling }} & \multicolumn{2}{|c|}{ Age Started to } & \multicolumn{2}{|c|}{ Age Started to } \\
\hline & & & & & & & & ork & Work S & Squared \\
\hline & Coeff. & Std. Error & Coeff. & Std. Error & Coeff. & Std. Errol & Coeff. & Std. Error & Coeff. & Std. Error \\
\hline Age & 0.016 & 0.024 & 0.901 & 0.670 & 0.112 & 0.022 & 0.016 & 0.024 & 0.920 & 0.674 \\
\hline Age Squared & -0.0004 & 0.0003 & -0.0148 & 0.0079 & -0.0018 & 0.0003 & -0.0004 & 0.0003 & -0.0151 & 0.0079 \\
\hline Black & 0.048 & 0.058 & -0.244 & 1.575 & -1.206 & 0.058 & 0.049 & 0.058 & -0.212 & 1.574 \\
\hline Pardo & -0.098 & 0.035 & -3.815 & 0.967 & -0.901 & 0.036 & -0.098 & 0.035 & -3.836 & 0.971 \\
\hline \multicolumn{11}{|l|}{ Father's Education } \\
\hline Some or Completed Lower Primary & 0.693 & 0.035 & 18.287 & 0.935 & 1.713 & 0.036 & 0.694 & 0.035 & 18.326 & 0.935 \\
\hline Some or Completed Upper Primary & 1.984 & 0.075 & 55.206 & 2.262 & 3.596 & 0.091 & 1.986 & 0.075 & 55.266 & 2.261 \\
\hline Some or Completed High School & 2.566 & 0.093 & 73.665 & 2.884 & 4.632 & 0.094 & 2.558 & 0.093 & 73.407 & 2.872 \\
\hline Some or Completed College & 3.697 & 0.126 & 112.580 & 4.166 & 5.489 & 0.106 & 3.716 & 0.125 & 113.184 & 4.144 \\
\hline \multicolumn{11}{|l|}{ Mother's Education } \\
\hline Some or Completed Lower Primary & 0.786 & 0.036 & 21.104 & 0.962 & 1.818 & 0.036 & 0.785 & 0.036 & 21.060 & 0.966 \\
\hline Some or Completed Upper Primary & 1.635 & 0.083 & 46.304 & 2.547 & 3.487 & 0.085 & 1.633 & 0.083 & 46.231 & 2.543 \\
\hline Some or Completed High School & 2.276 & 0.101 & 67.163 & 3.146 & 4.419 & 0.097 & 2.286 & 0.101 & 67.450 & 3.146 \\
\hline \multicolumn{11}{|l|}{ Some or Completed College } \\
\hline Other Indicator Variables & 2.318 & 0.169 & 69.334 & 5.532 & 4.545 & 0.148 & 2.324 & 0.169 & 69.581 & 5.551 \\
\hline Rural Area & -1.464 & 0.040 & -38.769 & 1.023 & -2.359 & 0.032 & -1.461 & 0.040 & -38.692 & 1.025 \\
\hline 1933 to 1958 Birth Year Cohort & 0.141 & 0.083 & 4.268 & 2.330 & 0.086 & 0.059 & 0.139 & 0.083 & 4.217 & 2.328 \\
\hline 1988 Year & 0.248 & 0.050 & 7.195 & 1.412 & -0.397 & 0.042 & 0.251 & 0.050 & 7.282 & 1.415 \\
\hline Great Regions & 0.008 & 0.017 & 0.227 & 0.485 & 0.200 & 0.015 & 0.010 & 0.017 & 0.269 & 0.486 \\
\hline \multicolumn{11}{|l|}{ North } \\
\hline Northeast & 0.426 & 0.086 & 10.631 & 2.493 & 0.053 & 0.085 & 0.424 & 0.086 & 10.537 & 2.484 \\
\hline South & 0.222 & 0.065 & 6.240 & 1.797 & -0.126 & 0.045 & 0.224 & 0.065 & 6.323 & 1.801 \\
\hline Center-West & -0.622 & 0.090 & -18.520 & 2.469 & -0.109 & 0.066 & -0.620 & 0.090 & -18.456 & 2.465 \\
\hline State GDP Per Capita at Age 25 & -0.644 & 0.074 & -17.456 & 2.000 & 0.404 & 0.065 & -0.641 & 0.074 & -17.361 & 2.000 \\
\hline \multicolumn{11}{|c|}{ Number of Schools per 1,000 Children by State } \\
\hline At Age 7 & 0.043 & 0.041 & 1.366 & 1.144 & -0.103 & 0.033 & 0.045 & 0.041 & 1.421 & 1.148 \\
\hline At Age 11 & 0.079 & 0.051 & 2.248 & 1.413 & 0.033 & 0.045 & 0.076 & 0.051 & 2.158 & 1.419 \\
\hline At Age 15 & -0.044 & 0.033 & -1.055 & 0.893 & 0.050 & 0.031 & -0.044 & 0.033 & -1.052 & 0.894 \\
\hline \multicolumn{11}{|l|}{ Number of Teachers per School by State } \\
\hline At Age 7 & 0.004 & 0.027 & 0.159 & 0.792 & -0.025 & 0.025 & 0.008 & 0.028 & 0.278 & 0.800 \\
\hline At Age 11 & 0.016 & 0.031 & 0.475 & 0.891 & -0.044 & 0.025 & 0.013 & 0.031 & 0.377 & 0.902 \\
\hline At Age 15 & 0.079 & 0.023 & 2.121 & 0.657 & 0.071 & 0.018 & 0.078 & 0.024 & 2.105 & 0.659 \\
\hline State GDP Per Capita at Age 12 & -0.012 & 0.030 & -0.512 & 0.862 & -0.072 & 0.027 & -0.014 & 0.030 & -0.581 & 0.867 \\
\hline Intercept & 11.102 & 0.543 & 119.123 & 15.214 & 2.158 & 0.476 & 11.103 & 0.546 & 118.820 & 15.306 \\
\hline R-Squared & 0.937 & & 0.794 & & 0.791 & & 0.937 & & 0.794 & \\
\hline Partial R-Squared & 0.0017 & & 0.0016 & & 0.0008 & & 0.0016 & & 0.0015 & \\
\hline Test of Excluded Instruments F(7, 916) & 10.14 & & 9.51 & & 5.14 & & 9.94 & & 9.34 & \\
\hline
\end{tabular}

Note: White-Huber robust standard errors were computed. 
Table A.5: IV Estimates - First Stage Regressions

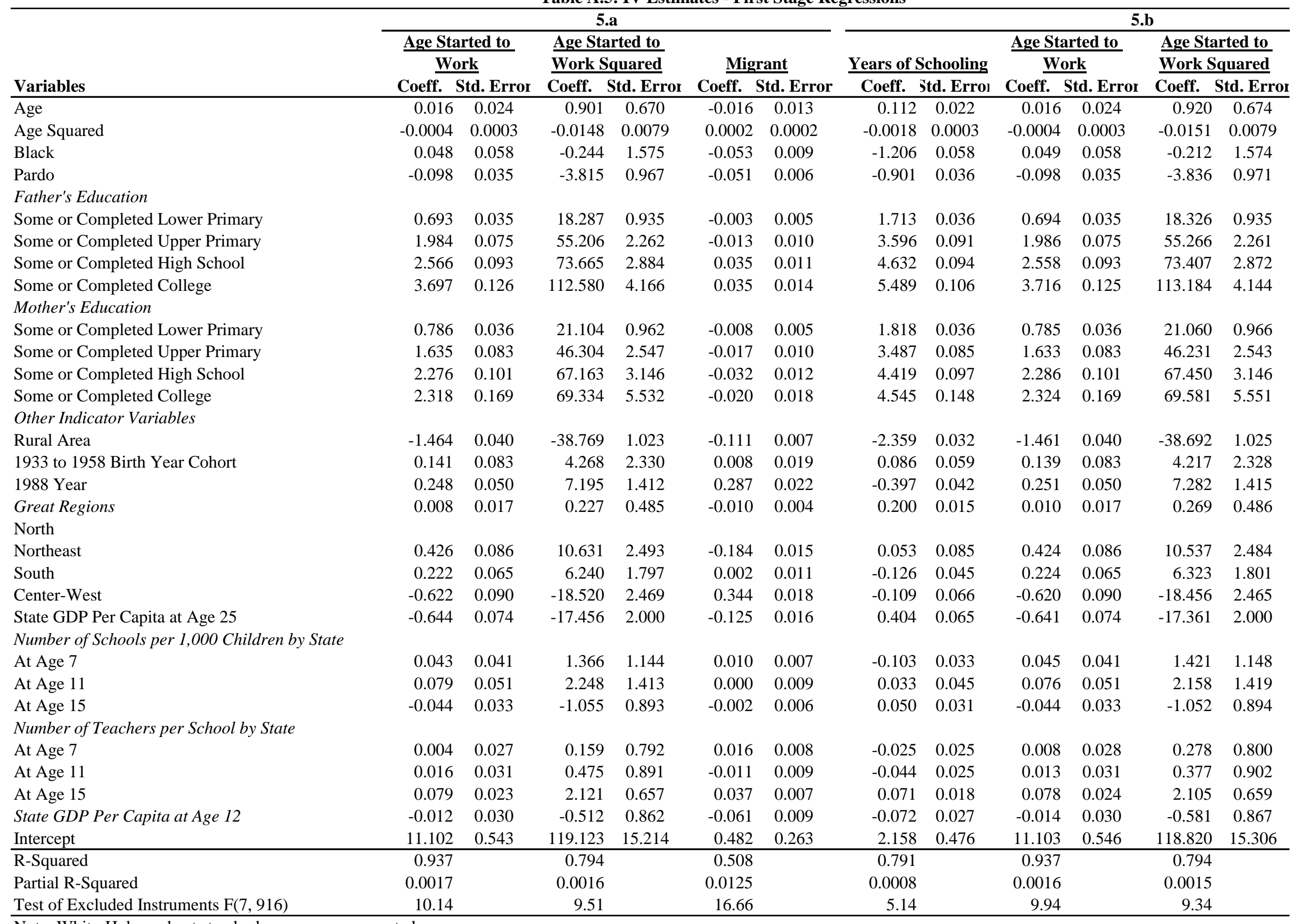

Note: White-Huber robust standard errors were computed. 
Table A.6: IV Estimates - First Stage Regressions

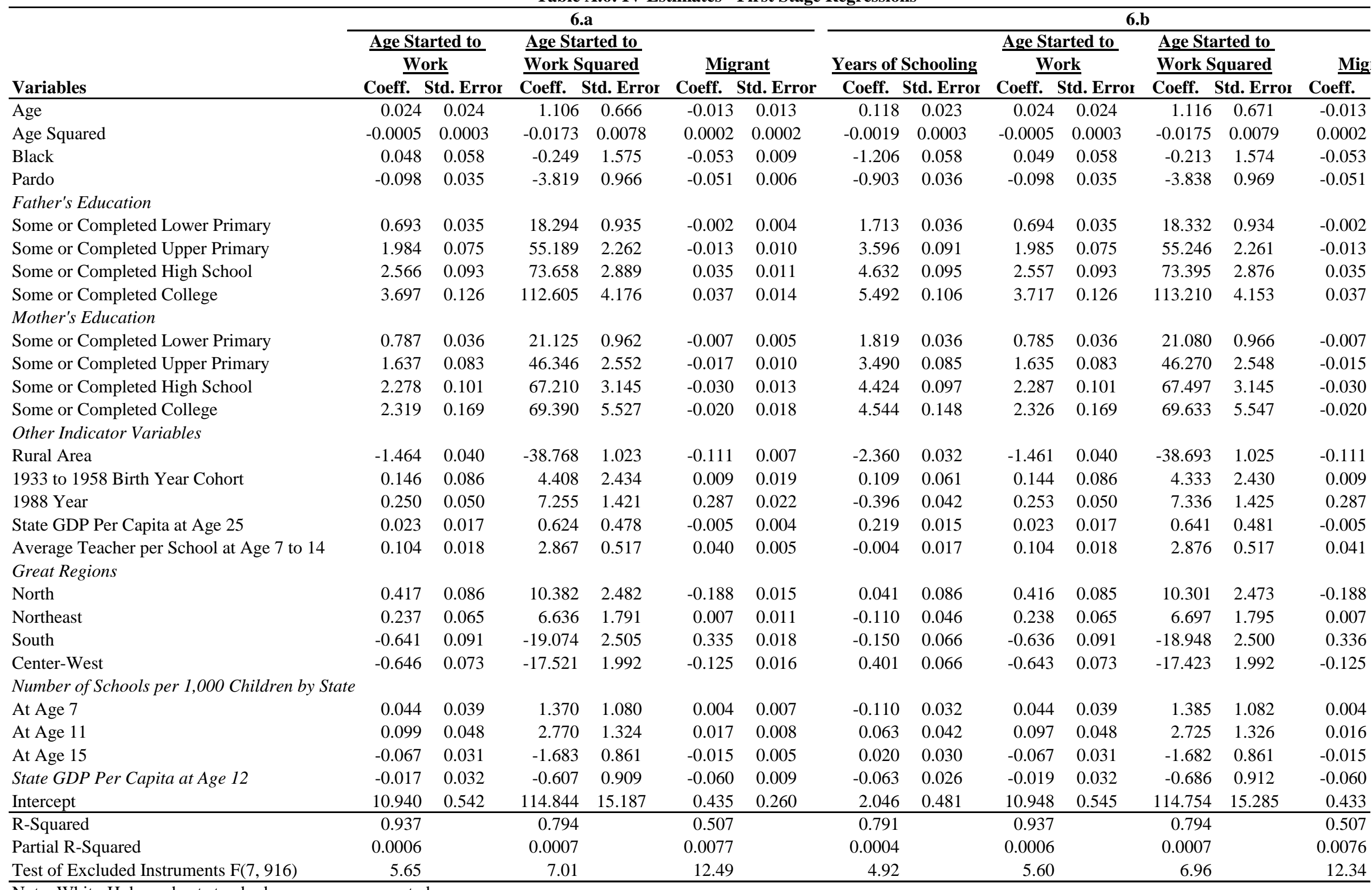

Note: White-Huber robust standard errors were computed. 


\section{Appendix B: School and Work}

To examine the joint school and work decision we look at two related sets of evidence. First, the 2001 PNAD has a special questionnaire on child labor in which child respondents were asked how many hours they stayed in school and how many hours they worked during the week (Sept. 23 to 29). ${ }^{30}$ This time allocation is divided into four categories: going to school only, going to school and working, working only, and not going to school and not working. Most of the male children attend school only, but a significant share work in the labor market, particularly those above ten years old. More importantly, most of those working go to school as well. For instance, among all 14 year old male children in 2001, 18 percent attend school and work and less then 4 percent work only. Interestingly, as they get older, they become more likely to go to school and work. The time at school distribution by age among 7 to 14 year old male children tells a similar story. The majority of children stay in school at least 4 hours a day and almost nobody stays more then 6 hours a day. Finally, from the same data we found that most of the male children that worked spent between 10 to 29 hours working and very few worked 40 hours or more. This contemporaneous evidence demonstrates that (i) the daily school schedule in Brazil allows ample time for children to engage in other activities, and (ii) most children who work, attend school as well. If this is the case now, it is very likely to have been the case among earlier generations. The evidence presented next supports this last point.

The second set of evidence is from retrospective information on age started to work and age at the time of the last grade obtained for heads of households and spouses only from the 1982 PNAD. ${ }^{31}$ We selected all head or spouse male individuals born between 1932 and 1964. We start with 1932 since it is the first cohort of our study, and stop in 1964 because after that date there are very few males that were considered head of households or the spouse of the head and because it was more likely that individuals were still in school. The distribution of age when last grade was obtained is concentrated between 12 and 18 years old. By 18 years old, more than 80 percent of these individuals had finished or abandoned formal school. We also found the average age when the individual obtained their highest grade and the average age when individuals started to work by the year of their birth. For all birth years, the average age started to

\footnotetext{
${ }^{30}$ This is the week of reference of the 2001 PNAD survey. The PNADs go to the field every September of a year.

${ }^{31}$ The 1982 PNAD is an interesting survey to study the school to work transition since it has information on the age when the individual obtained the last grade of education, whereas the other PNADs don't. However, it does not have
} 
work is lower than the average age when the last grade was completed. Similar to the 1988 and 1996 figures, the average age started to work ranges between 12 and 13 years old. The average age when the last grade was obtained ranges between 14.5 to 17 years old. This shows that the average age started to work is always below the average age when the last grade was obtained, suggesting that representative individuals of all these generations were going to school and engaging in some labor market activity. Of course, these averages do not tell us if there were many individuals going to school and working. There could be two separate groups: individuals who only attend school and individuals who only work. However, it is clear that this is not the case from an examination of the time allocation distribution by year of birth. For each individual from the 1982 sample we know their final educational attainment. So we classified each in one of the three categories: (i) if illiterate we classified an individual as not having gone to school; (ii) if an individual has some schooling and has an age started to work that is strictly less than the age when he obtained his last grade we classified him as going to school and work; and (iii) if an individual has some schooling and has an age started to work that is equal or greater than the age when he obtained his last grade we classified him as going to school only. The majority of each male generation went to school and worked. It ranges from 40 percent in the 1932 birth year cohort to 60 percent in the 1960 cohort. Interestingly, the no school fraction decreases through the years. Since the school only fraction remains relatively stable and the school and work fraction increases, it suggests that the school expansion in this period was driven by more individuals both going to school and working.

information on state of birth so we are not able to assign the corresponding instruments to each individual. It is for this reason we do not include the 1982 PNAD in this study. 


\section{Appendix C: The Construction of the Number of Schools and the Number of Teachers}

The data for number of schools and number of teachers come from IBGE (2003). The Brazilian formal education system has changed during the $20^{\text {th }}$ century, and the data are aggregated accordingly. ${ }^{32}$ If we divide the system into three categories: lower primary (first to fourth grades), upper primary (fifth to eight grades), and secondary (ninth to eleventh grade), the data is organized as follows. Until 1972 the data were divided into lower primary on one side and upper primary and secondary together on the other side. After 1973, lower and upper primary were aggregated and secondary were separated. Thus, in order to be consistent for the overall period we pooled all lower primary, upper primary and secondary education data. These data also include the number of professional schools and teachers in professional schools.

Additional adjustments were made due to the characteristics of the data. There were no figures for the years 1949, 1950, and 1951. For these years we attributed the state averages between 1948 and 1952. For a very few outliers, we attributed the average figure between the adjacent years. For the territories that were created in 1943 we needed to construct their figures back to 1939. For these cases, we use the first number of schools (or teacher) available for the territories and the numbers of the state they were created. We obtained the fraction of number of schools (or teachers) between the territory and the state for those years and used these ratios to compute the series for the previous years. Finally, the figures for primary and secondary schools (or teachers) for the years 1967 to 1977 were constructed from information on courses rather than establishments using figures of courses by establishments in the 1964 to 1966 years. From these, we obtained the ratio of courses per establishment by state using the 1964 to 1966 figures and then used these ratios to compute the number of schools (or teachers) by state for the 1967 to 1977 years. To properly assign the correct number of schools and teachers to individuals, those that were born from the months of January to June were assigned the number of schools and teachers in the state at each age for that year, and those born from July to December received the number of schools and teachers for the following year, to account for the school year division in Brazil. The figures for the overall population and children aged 5 to 19 by state come from the IBGE census data. The census years are 1940, 1950, 1960, 1970, 1980, and 1991. The figures between census years were obtained by computing for each state and decade the population growth geometric mean.

\footnotetext{
${ }^{32}$ See Plank (1996).
} 


\section{Appendix D: Brazilian Territorial Division}

Brazil has experienced changes in its territorial division during the 20th century. Some states were created by divisions of other states and others were merged together. In order to maintain a consistent division throughout the period studied, we performed the following classification.

Territories or states that no longer exist that were merged to the states in which they were incorporated:

Territory of Iguaçu - incorporated to Paraná

Territory of Ponta-Porã - incorporated to Mato Grosso

Guanabara - incorporated to Rio de Janeiro

Current states created from a division of previous states were merged together:

Mato Grosso do Sul - merged with Mato Grosso

Tocantins - merged with Goiás

Old federal territories that became states were considered states:

Territory of Rio Branco - separated from the state of Amazonas in 1943, becomes

Territory of Roraima in 1962, and state of Roraima in 1988.

Territory of Guaporé - separated from parts of Amazonas and Mato Grosso in 1943, becomes territory of Rondônia in 1956, and state of Rondônia in 1981.

Territory of Amapá - separated from state of Pará in 1943 and becomes state of Amapá in 1988. 
Brazil is divided into five great regions. By the late 1960's, the division was the following:

Table E.1: States and Old Great Regions

\begin{tabular}{|c|c|}
\hline Region & State Name \\
\hline North & $\begin{array}{l}\text { Rondônia } \\
\text { Acre } \\
\text { Amazonas } \\
\text { Roraima } \\
\text { Pará } \\
\text { Amapá }\end{array}$ \\
\hline Northeast & $\begin{array}{l}\text { Maranhão } \\
\text { Piauí } \\
\text { Ceará } \\
\text { Rio Grande do Norte } \\
\text { Paraíba } \\
\text { Pernambuco } \\
\text { Alagoas }\end{array}$ \\
\hline East & $\begin{array}{l}\text { Sergipe } \\
\text { Bahia } \\
\text { Minas Gerais } \\
\text { Espírito Santo } \\
\text { Rio de Janeiro }\end{array}$ \\
\hline South & $\begin{array}{l}\text { São Paulo } \\
\text { Paraná } \\
\text { Santa Catarina } \\
\text { Rio Grande do Sul }\end{array}$ \\
\hline Center West & $\begin{array}{l}\text { Mato Grosso \& Mato Grosso do Sul } \\
\text { Goiás \& Tocantins } \\
\text { Distrito Federal }\end{array}$ \\
\hline
\end{tabular}

